\title{
Physiological Study on Jerusalem Artichoke Plants (Helianthus Tuberosus L.) Under Two Types of Soils
}

\author{
Nashwa I. Abo El-Fadel ${ }^{1}$, Sameh A.M. Moussa ${ }^{1}$ and Mostafa A. Shama²
}

\begin{abstract}
Two field experiments were carried out on Jerusalem artichoke crop during two successive seasons of 2016 and 2017 at Soil Salinity Laboratory Research, Agricultural Research Center, Alexandria Governorate, Egypt. Each experiment included sixteen treatments representing the combination of two types of soils; i.e., clay and calcareous, two trimming treatments; i.e., without trimming $\left(\mathrm{T}_{0}\right)$ and trimming $\left(T_{1}\right)$ [removing of flowering buds before opening with $10-20 \mathrm{~cm}$ from ends of vegetative branches], and four fertilization treatments; i.e., $75 \mathrm{~kg}$ nitrogen/feddan + Halex-2 $\left(F_{1}\right), 75 \mathrm{~kg}$ nitrogen/feddan + yeast extract $\left(F_{2}\right), 75$ kg nitrogen/feddan + Halex-2 + yeast extract $\left(F_{3}\right)$ and 100 $\mathrm{kg}$ nitrogen/feddan $\left(\mathrm{F}_{4}\right)$. The experimental layout was presented as a split-split-plot in a randomized complete blocks design with three replicates. Two types of soil were assigned in the main plots; two trimming treatments were allocated to the sub-plots and four fertilization treatments which were, randomly, distributed in the sub-sub-plots. Planting Jerusalem artichoke tubers in clay soil encouraged each of the vegetative growth, yield and its component characters compared to planting in calcareous soil. Un-trimming Jerusalem artichoke growing plants resulted in positive effects on the vegetative characters, tubers' yield and its components traits compared to trimming treatment. Adding moderate amount of nitrogen fertilizer ( $75 \mathrm{~kg} \mathrm{~N}$ / fed.) combined with Halex-2 plus yeast extract yielded statistically equal results if $100 \mathrm{~kg} \mathrm{~N} / \mathrm{fed}$. was added to the growing plants for most studied characters especially the economic ones. Maturity date trait did not affect with any of the applied treatments on Jerusalem artichoke growing plants. It turned out from the obtained results that a quarter of nitrogen fertilizer quantity could be saved by adding a mixture of biostimulants (Halex-2 + yeast extract) to the growing plants, in addition to un-trimming the ends of branching whether the cultivation was in clay or calcareous soils.
\end{abstract}

Key words: Jerusalem artichoke, trimming, biofertilizer, Halex-2 and yeast extract.

\section{INTRODUCTION}

Jerusalem artichoke (Helianthus tuberosus L.) is considered as an important non-traditional vegetable crop. It is a promising crop; especially it is grown in new reclaimed soils. Jerusalem artichoke tubers typically comprise about $80 \%$ water. It may play an important role in human nutrition as sources for protein
(1-2\%), carbohydrates (15\%), vitamins, inulin (up to 20 $\%)$ and minerals especially iron (0.4 to $3.7 \mathrm{mg} 100 \mathrm{~g}-1)$, calcium (14 to $37 \mathrm{mg} / 100 \mathrm{~g}$ ) and potassium (420-657 mg / 100 g) (Baker et al., 1990; Whitney and Rolfes, 1999 and Kocsis et al., 2008). It also has beneficial medical effect, especially for diabetic patients. Also, Jerusalem artichoke can be used in food industry and important source for ethanol production (Rodrigues $e t$ al., 2007).

The availability of plant nutrients are powerfully related to the properties of soils. Calcareous soils are one of the very important factors that limit the nutrients' availability. Calcareous soils are familiar in arid and semi-arid climates affecting more than 600 million ha soils of the world (Leytem and Mikkelsen, 2005). In calcareous soils where $\mathrm{pH}$ is high and $\mathrm{CaCO}_{3}$ is dominated, plants suffer low availability of $\mathrm{P}$ and $\mathrm{K}$ would cause troubles more dangerous than their deficiencies. Micronutrients deficiency is one of the highly critical abiotic stresses in plants grown on calcareous soils (Xudan, 1986; Kulikova, et al., 2002). Generally, calcareous soils are considered as very fragile with respect to agricultural production owing to their very low nutrients and organic matter content. Agricultural productivity on such soils is hence considerably low. Generally, Calcareous soils have low organic matter content and lack of nitrogen .Nitrogen fertilizer may be applied any time from just prior planting up to the time the plant is well established (FAO, 1977). Anyhow, the potential productivity of calcareous soils is high where sufficient water and nutrients can be provided.

Yeast as a natural stimulator is characterized by its richness in protein $(47 \%)$, carbohydrates $(33 \%)$, nucleic acid (8\%), lipids (4\%) and different minerals (8\%) such as $\mathrm{Na}, \mathrm{Fe}, \mathrm{Mg}, \mathrm{K}, \mathrm{P}, \mathrm{S}, \mathrm{Zn}, \mathrm{Mn}, \mathrm{Cu}, \mathrm{Si}, \mathrm{Cr}, \mathrm{Ni}, \mathrm{Va}$ and $\mathrm{Li}$, in addition to thiamin, riboflavin, pyridoxine, hormones and other growth regulating substances, such as biotin, B12 and folic acid (Nagodawithana, 1991). It also, considered a natural source of cytokinins and has stimulatory effects on bean plants (Amer, 2004). Foliar application of yeast could be of a great importance for plants grown under calcareous soil conditions. In this concern, yeasts have been stated to be rich source of

\footnotetext{
DOI: 10.21608/ASEJAIQJSAE.2019.31622

${ }^{1}$ Sabaheya Horticultural Research Station, Horticulture Research Institute, A.R.C., Egypt.

${ }^{2}$ Soil Salinity Department; Soil, Water, and Environment Research Institute; A.R.C., Egypt.

Received April 02, 2019, Accepted May 10, 2019
} 
phytohormones (especially cytokinins), vitamins, enzymes, amino acids and minerals (Barnett et al., 1990; Fathy and Farid, 1996; Khedr and Farid, 2000 and Mahmoud, 2001). Also, the stimulatory influences of yeast on cell division and enlargement, protein and nucleic acid synthesis and chlorophyll creation were informed by (Kraig and Haber, 1980, Castelfranco and Beale, 1983, Wanas, 2002 and Wanas, 2006). In another study, the usage of active yeast extract enriched growth and productivity of vegetable crops, due to its cytokinins content (Barnett et al., 1990). Yeast extract has stimulatory effects on plant growth and its productivity as reviewed by numerous authors on their studies on vegetative propagation crops (Ghoneim, 2005 on artichoke), (El-Ghinbihi and Ali, 2001, Taha and Omar, 2010 and Ahmed et al., 2011 on potatoes), and (Shalaby and El-Ramady, 2014 and Moussa et al., 2017on garlic).

Halex-2 is a bio-fertilizer which considers nonsymbiotic nitrogen fixing bacteria (Azospirillum, Azotobacter and Klebbsilla). This bio-fertilizer has greater amounts of bacteria which responsible for fixing of nitrogen. Usage of Halex-2 to the cultivating plants attained the resulting values: increasing soil fertility, decreasing the usage of nitrogen fertilizers and expanding the availability of diverse nutrients to plant absorption (Abdel-Razzak and El-Sharkawy, 2013). Fayez et al. (1985) illustrated that free-living nitrogen fixing bacteria; e.g., Azotobacter chroococcum and Azospirillum lipoferum, were realized to have not only the capability to fix nitrogen but also the ability to release phytohormones similar to gibberellic acid and indole acetic acid which could motivate plant growth, absorption of nutrients and photosynthesis. Many researchers proved that utilizing bio-fertilizers (nonsymbiotic nitrogen fixing bacteria) such as Halex 2, reflected positively effects on the vegetative growth, productivity and quality of numerous important vegetative propagation crops like potato (El-Gghinbihi and Ali, 2001 and Feleafel, 2005), globe artichoke (Ghoneim, 2005), and garlic (Moussa et al., 2017).

Trimming or pruning is the removal or reduction of certain plant parts that are not required, that are no longer effective, or that are of no use to the plant. Trimming (hand thinning of flowers) encourages plants to thrive. It has been known since the 1930s that the plant hormone auxin is released by the plant's actively growing tip and is transported down the main stem where it has an indirect effect on buds to inhibit branching (Reed, 2009). It is done to supply additional energy for the development of fruits, and limbs that remain on the plant. Trimming "pruning" or removing the ends of main branches growing points encouraged basal branching and accelerate branch growth (Rubinstein and Nagao, 1976; Wein and Minotti, 1988). A number of studies have taken care of this subject and reported the positive effects of trimming (pruning) on the vegetative growth characters, yield and its quality parameters (Olasantan, 1986; El-Assiouty, 1988 and Ghoneim, 2000 on okra plants and Barakat and AbdelRazik, 1990 on tomato plants).

The present study was designed to investigate the effect of some cropping practice such as nitrogen, biofertilizers (Halex-2 and yeast extract) and trimming treatments on improving growth characteristics, tuber's yield and its components, as well as tubers' quality and chemical compositions of Jerusalem artichoke. Early maturity of the crop was also considered in this study through trimming treatment. Also, the objectives are to improve the productivity of Jerusalem artichoke plants by using lower doses of chemical nitrogen fertilizers compared to the recommended dose without any negative effects on the tubers' quality.

\section{MATERIALS AND METHODS}

Two experimental studies were carried out during the successive seasons of 2016 and 2017at Soil Salinity Laboratory Research, Alexandria, Agricultural Research Center. Tubers of Fuseau cultivar of Jerusalem artichoke were used in this study. The study was conducted in concrete lysimeters [1 m (L) x $1 \mathrm{~m}$ (W) x $2 \mathrm{~m}$ (D)]. Whole tubers within the weight range of 30-35 gram each were sown on the $1^{\text {th }}$ of April during both seasons. Tubers' yield was harvested at the end of November. Each experiment included sixteen treatments representing the combination of two types of soils; i.e., clay and calcareous, two trimming treatments; i.e., without trimming $\left(\mathrm{T}_{0}\right)$ and trimming $\left(\mathrm{T}_{1}\right)$ and four fertilization treatments; i.e., $75 \mathrm{~kg}$ nitrogen/feddan + Halex-2 $\left(\mathrm{F}_{1}\right), 75 \mathrm{~kg}$ nitrogen/feddan + yeast extract $\left(\mathrm{F}_{2}\right)$, $75 \mathrm{~kg}$ nitrogen/feddan + Halex-2 + yeast extract $\left(\mathrm{F}_{3}\right)$ and $100 \mathrm{~kg}$ nitrogen/feddan $\left(\mathrm{F}_{4}\right)$. Tubers were planted one in each plot (experimental unit). During the two growing seasons, all other recommended agro-managements such as irrigation, disease pests and weed control were performed whenever they appeared to be necessary. Some of the physical and chemical properties of the two types of soils were measured using laboratory tests suggested by the U.S. Salinity Laboratory Staff (1954) are presented in Table (1). 
Table 1. Some physical and chemical properties of the experimental soils (average of the two seasons)

\begin{tabular}{|c|c|c|c|c|c|c|c|c|c|c|c|}
\hline \multirow[b]{2}{*}{ Soil type } & \multicolumn{3}{|c|}{ Physical properties } & \multirow{2}{*}{\multicolumn{2}{|c|}{ Soil texture }} & \multirow{2}{*}{\multicolumn{2}{|c|}{ pH }} & \multirow[b]{2}{*}{$\begin{array}{l}\text { EC. } \\
\text { dS/m }\end{array}$} & \multirow[b]{2}{*}{$\mathrm{CaCo}_{3} \%$} & \multirow{2}{*}{\multicolumn{2}{|c|}{ O.M.\% }} \\
\hline & $\begin{array}{l}\text { Sand } \\
\%\end{array}$ & $\begin{array}{l}\text { Silt } \\
\%\end{array}$ & $\begin{array}{c}\text { Clay } \\
\%\end{array}$ & & & & & & & & \\
\hline Calcareous & 55 & 25 & 20 & \multirow{2}{*}{\multicolumn{2}{|c|}{$\begin{array}{c}\text { sandy clay loam } \\
\text { clay loam }\end{array}$}} & \multirow{2}{*}{\multicolumn{2}{|c|}{$\begin{array}{l}8.16 \\
7.84\end{array}$}} & 1.95 & 32.0 & & 1.36 \\
\hline Clay & 34 & 30 & 36 & & & & & 1.63 & 2.80 & & 2.14 \\
\hline \multicolumn{12}{|c|}{ Chemical properties } \\
\hline & \multicolumn{4}{|c|}{$\underline{\text { Soluble cations }(\mathrm{meq} / \mathrm{L})}$} & \multicolumn{4}{|c|}{ Anions (meq/L) } & \multicolumn{3}{|c|}{ Soil available } \\
\hline & $\mathrm{Ca}^{++}$ & $\overline{\mathrm{Mg}^{++}}$ & $\mathrm{Na}^{+}$ & $\mathrm{K}^{+}$ & $\mathrm{CO}_{3}^{-}$ & $\mathrm{HCO}_{3}^{-}$ & $\overline{\mathrm{CL}^{-}}$ & $\mathrm{SO}_{4}^{--}$ & $\mathrm{N} \%$ & $\mathrm{P} \%$ & $\mathrm{~K} \%$ \\
\hline Calcareous & 6.40 & 4.62 & 5.95 & 1.22 & - & 8.01 & 7.75 & 2.43 & 0.32 & 0.15 & 0.48 \\
\hline Clay & 4.80 & 3.80 & 5.40 & 0.68 & - & 5.54 & 5.76 & 3.38 & 0.56 & 0.32 & 0.40 \\
\hline
\end{tabular}

\section{Agricultural practices}

The following fertilizers were added to the soil at preparation; $5 \mathrm{~m}^{3}$ organic manure /fed., $75 \mathrm{Kg}$ $\mathrm{P}_{2} \mathrm{O}_{5} /$ fed.in the form of mono calcium phosphate $(15.5$ $\left.\% \mathrm{P}_{2} \mathrm{O}_{5}\right)$ and $100 \mathrm{~kg} \mathrm{~S} / \mathrm{fed}$. Nitrogen fertilizer was added in the form of ammonium sulphate $\left(\mathrm{NH}_{4}\right)_{2} \mathrm{SO}_{4}, 20.6 \%$ $\mathrm{N})$ in three equal doses. The first dose was added one month after planting. The second and third doses were added two and three months later from the first dose. Potassium fertilizer was added at the rate of $120 \mathrm{Kg}$ $\mathrm{K}_{2} \mathrm{O} / \mathrm{fed}$. in two equal doses in the form of potassium sulphate $\left(48 \% \mathrm{~K}_{2} \mathrm{O}\right)$. The first dose was added with the second addition of nitrogen fertilizer, while the second half was added with the third dose of nitrogen fertilizer. Trimming treatment was done 5 months later from planting by removing the flowering buds before blooming with about $10-20 \mathrm{~cm}$ from the ends of the branches. This process lasted for two consecutive weeks (flowering stage).

\section{Source of the bio-stimulants}

Halex-2 is a bio-fertilizer comprised mixed inoculation of non-symbiotic $\mathrm{N}$-fixing bacteria of genera Azospirillum, Azotobacter and Klebsiella. Halex-2 was kindly provided by the Bio-fertilization Unit, Department of Plant Pathology, The Faculty of Agriculture, Alexandria University. Egypt. Tubers were inoculated by soaking in suspension of the Halex-2 containing 5\% Arabic gum, at the rate of $400 \mathrm{~g} / \mathrm{fed}$. for half an hour before planting according to the recommendation of the above mentioned department. The inoculation with Halex-2 was repeated two months later as side dressing beside the growing plants (Ghoneim, 2005).

Yeast extract:- The brewer's yeast (Saccharomyces cerevisiae) was dissolved in water. Sugars were added to the yeast at a ratio of 1:1. The extract was kept for 24 hours in a warm place for reproduction, as explained by Morsi et al. (2008). The yeast extract was added as soon as tubers' planting. The yeast extract was added to the growing plants for the second time after two months from planting.

\section{Measurements:}

\section{Vegetative growth and yield parameters:}

Each plant in each experimental unit was taken to measure the studied vegetative growth characters (Plant height (m) and number of branches / plant), tubers' yield / feddan and yield components (average tuber weight / plant $(\mathrm{kg})$ and number of tubers / plant). The vegetative growth characters were recorded on the growing plants at the end of flowering stage; while the data of the tubers' yield and its component characters were recorded at harvesting date. Maturity period (days) was determined by counting the days from planting till harvest of the crop.

\section{Tubers' quality:}

Random samples of ten tubers per treatment were randomly used. Percentage of tubers' dry weight calculated by drying $100 \mathrm{gm}$ of fresh sliced tubers in an electric air - drying oven at $70 \mathrm{c}^{\circ}$ till constant weight. Each dried sample was ground to powder. Inulin content was determined in tubers according to the method of Winton and Winton (1958). Tubers' starch percentage (\%) was determined using a sample of $1 \mathrm{~g}$ of dried tuber, according to the method described in A.O.A.C. (1990).

\section{Tubers' mineral contents:}

A sample of $0.5 \mathrm{~g}$ from the ground material was digested with sulphuric acid by hydrogen peroxide according to Evenhuis and De Waard (1980). Aliquots were then taken for mineral determination. Nitrogen was determined according to A.O.A.C. (1990). Phosphorus was determined colorimetrically following Murphy and Riley (1962). Potassium was determined against a standard using air propane flame photometer following Chapman and Pratt (1961). The concentration of N, P and $\mathrm{K}$ were expressed as percentage. 


\section{Experimental design and statistical analysis}

The experimental design used was a split-split-plot in a randomized complete blocks design (R.C.B.D) with three replicates. Two types of soil were assigned in the main plots; two trimming treatments were allocated to the sub-plots and four fertilization treatments which were, randomly, distributed in the sub-sub-plots. Collected data of the experiments were statistically analyzed using the analysis of variance method. Comparisons among the means of different treatments were done, using least significant differences (L.S.D) test procedure at $p=0.05$ level of probability, as illustrated by Snedecor and Cochran (1980). Computation was done using Co-Stat software program (2004).

\section{RESULTS AND DISCUSSION}

\section{Plant growth characters}

\section{Effects of soil types on the vegetative growth}

The results of Table (2) showed that soil type had significant effects on the vegetative growth characters. The differences between soils types showed that plant height was significantly higher when Jerusalem artichoke plants were grown in clay soil during the two seasons.Same trend of results were also detected for number of branches / plant, where the highest mean value was given when Jerusalem artichoke plants were grown in clay soil during the two seasons. These results may be due to soil characteristics at most $\mathrm{CaCO}_{3} \%, \mathrm{pH}$ and texture. Soils with high values of $\mathrm{CaCO}_{3} \%$ and $\mathrm{pH}$ may suffer from low availability of soil nutrients. Soil texture is the important properties of the soil and affects the rate of water absorption, aeration, micronutrient transport availability and soil fertility (Tan, 2003).

\section{Effects of trimming treatments on the vegetative growth}

The data of Table (2) showed that un-trimming treatment significantly gave the highest mean values for plant height trait during the two seasons. On the other side, there was insignificant differences between the two trimming treatments (trimming and un-trimming) for number of branches per plant character across the two seasons. The results of Ghoneim (2000) on okra plants and Al-Obidy (2011) on roselle plants appeared that decapitation pinching led to significant increments in most studied vegetative growth characters except for plant height. This may be due to the fact that pinching may limits the formation of gibberellin found in the developing peaks in the roots and the stems which responsible for plant elongation and the tendency of the plant to give lateral growth instead of longitudinal growth.

\section{Effects of fertilization treatments on the vegetative growth}

As for plant height and number of branches/ plant traits, the recorded data showed that both the fertilization treatments $F_{3}$ and $F_{4}$ significantly possessed the highest mean values during the two seasons; while both the fertilization treatments $F_{1}$ and $F_{2}$ gave the lowest mean values (Table, 2). It turned out from the previous results the role of the applied bio-stimulants as a mixture of Halex-2 and yeast extract on the positive stimulation of the vegetative growth characteristics of Jerusalem artichoke plants. This result is accordance with those obtained by Ghoneim (2005) and Shafeek et al. (2012). The authors demonstrated that inoculation the growing plants with bio-fertilizers simulative the vegetative growth characters. Shafeek et al. (2012) explained that this superiority may be assigned to the microorganisms' inoculation, in the first place, enriched the rhizosphere with these bacteria. Furthermore, these microbial inoculation encourage plant growth either directly, by producing plant hormones and improving nutrient uptake, or indirectly, by altering the microbial balance in rhizosphere in favor of the useful microorganisms (Amara et al., 1995 and Lazarovits and Nowak 1997). Furthermore, N-biofertilizer bacteria enhanced the plant growth by $\mathrm{N}$-fixing in the cultivated soil and /or contributing some growth hormones like gibberellins, auxins and cytokinins (Cacciari et al. 1989). Recently, this beneficial effect was compatible with those obtained with Zhongyong et al. (2006), Luo et al. (2008) and Leaungvutiviroj et al. (2010) on cassava plants.

\section{Effects of interactions on the vegetative growth}

The obtained data of Table (2) illustrated that the interactions between soil types and trimming treatments were significant for the studied vegetative characters. The interaction (clay $\mathrm{x} \mathrm{T}_{0}$ ) significantly gave the highest mean values for plant height. As for number of branches / plant; the recorded data showed that the two interactions (clay $\times \mathrm{T}_{1}$ ) and (clay $\mathrm{x} \mathrm{T}_{0}$ ) significantly gave the highest mean values during the two seasons. The results of the interaction between soil type and fertilization treatment (Table, 2) showed that, the two interactions (clay $\times \mathrm{F}_{3}$ ) and (clay $\mathrm{x}_{4}$ ) significantly gave the highest mean values for both plant height and number of branches / plant traits during the two seasons. The results of Table (2) for plant height character showed that, the interactions $\left(\mathrm{T}_{0} \times \mathrm{F}_{3}\right)$ and $\left(\mathrm{T}_{0} \times \mathrm{F}_{4}\right)$ significantly gave the highest mean values during the two seasons. With regard to number of branches / plant, the results of the two seasons showed that each of the interactions $\left(\mathrm{T}_{1} \times \mathrm{xF}_{3}\right),\left(\mathrm{T}_{1} \times \mathrm{xF}_{4}\right),\left(\mathrm{T}_{0} \times \mathrm{F}_{3}\right)$ and $\left(\mathrm{T}_{0} \times \mathrm{F}_{4}\right)$ significantly possessed the highest mean values in this respect. Generally, it is clear from the previous results 
that there is a positive effect of un-trimming treatment in its interaction with the soil types or with fertilization treatments on the effect of the studied vegetative traits. The positive effect of bio-stimulants as a mixture of Halex-2 and yeast extract was also demonstrated through its interaction with the soil types or with the trimming treatments. The positive effects of tested biostimulants on the vegetative characters were mainly due to the role of Halex-2 in increasing the availability of $\mathrm{N}$ to plant absorption and containing yeast cytokinins, enzymes, vitamins, minerals and amino acids which have positive role on cell division and elongation, nucleic acid synthesis, protein and chlorophyll formation (Khedr and Farid, 2000, Mahmoud, 2001).

Generally, the interactions between soil types $\mathrm{x}$ trimming treatments $\mathrm{x}$ fertilization treatments showed significant effects for plant height and number of branches / plant across the two seasons of this study (Table, 2). The interactions (clay $\mathrm{x}_{0} \times \mathrm{F}_{3}$ ) and (clay $\mathrm{x}$ $\mathrm{T}_{0} \times \mathrm{F}_{4}$ ) significantly gave the highest mean values for plant height trait during the first season. As for the second season, the results showed that the three interactions (clay $\times \mathrm{T}_{1} \times \mathrm{F}_{4}$ ), (clay $\times \mathrm{T}_{0} \times \mathrm{F}_{3}$ ) and (clay $\mathrm{x}$ $\begin{array}{lll}\mathrm{T}_{0} & \mathrm{x} & \left.\mathrm{F}_{4}\right)\end{array}$ were superior to the rest of the tested interactions. As for number of branches / plant, it appears from the data of Table (2) that the each of the interactions (clay $\times \mathrm{T}_{1} \times \mathrm{F}_{3}$ ), (clay $\times \mathrm{T}_{1} \times \mathrm{F}_{4}$ ), (clay $\times \mathrm{T}_{0}$ $\times F_{3}$ ) and (clay $\times T_{0} \times F_{4}$ ) significantly possessed the highest mean values during the two seasons. The results of (Tony, 2013) showed that the bio-stimulants improved plant height and some other vegetative characters of Jerusalem artichoke plants only when 50\% of the $\mathrm{N}$ recommended dose was applied. The results of Table (2) illustrated that the interaction formulations containing mixture of bio-stimulants (Halex-2 and yeast extract) statistically gave results equal to the treatment containing $100 \%$ of the recommended amount of nitrogen (100 kg nitrogen/feddan) for the vegetative traits. Bio-fertilizers able to enhance vegetative growth, mineral nutrient uptake and improve the yielding of many plants (Fayad, 2005; Fathy et al., 2008 and Hassan et al., 2008). Many researches proved the benefit role of yeast extract on stimulating the vegetative growth of plants; i.e., Ghoneim, (2005) on artichoke; ElGhinbihi and Ali (2001), Taha and Omar (2010) and Ahmed et al. (2011) on potatoes. The authors illustrated that yeast extract had favorable influence on the plant metabolism and biological activity through stimulating photosynthetic pigments and enzyme activity which in turn promote the plant vigorous. Apte and Shende (1981) reported that the inoculation substances might change the microflora in the rhizosphere and affect the balance between harmful and beneficial organisms. Similar findings were recorded by Sorial et al. (1998), on globe artichoke who indicated that the application of Promote bio-fertilizer; mixtures of fungus and yeast; significantly stimulated plant height, number of leaves /plant and leaf dry matter content.

Table 2.Mean performances of the vegetative characters of Jerusalem artichoke plants during the seasons of 2016 and 2017

\begin{tabular}{|c|c|c|c|c|c|c|}
\hline \multicolumn{3}{|c|}{ Treatments } & \multirow{2}{*}{\multicolumn{2}{|c|}{ Plant height (m) }} & \multirow{2}{*}{\multicolumn{2}{|c|}{ No. of branches/ plant }} \\
\hline \multirow{3}{*}{ Soil type } & \multirow[t]{3}{*}{ Trimming } & \multirow{3}{*}{$\begin{array}{c}\text { Fertilization } \\
\text { treatments }\end{array}$} & & & & \\
\hline & & & \multicolumn{4}{|c|}{ Seasons } \\
\hline & & & 2016 & 2017 & 2016 & 2017 \\
\hline \multicolumn{3}{|l|}{ Calcareous } & $2.63 b$ & $2.49 b$ & $15.63 b$ & $13.04 \mathrm{~b}$ \\
\hline \multirow[t]{7}{*}{ Clay } & & & $3.23 \mathrm{a}$ & $2.89 \mathrm{a}$ & $18.50 \mathrm{a}$ & $15.38 \mathrm{a}$ \\
\hline & $\mathrm{T}_{1}$ & & $2.85 b$ & $2.54 \mathrm{~b}$ & $17.25 \mathrm{a}$ & $14.38 \mathrm{a}$ \\
\hline & $\mathrm{T}_{0}$ & & $3.02 \mathrm{a}$ & $2.84 \mathrm{a}$ & $16.88 \mathrm{a}$ & $14.04 \mathrm{a}$ \\
\hline & & $\mathrm{F}_{1}$ & $2.86 \mathrm{~b}$ & $2.50 \mathrm{~b}$ & $16.17 \mathrm{~b}$ & $13.08 b$ \\
\hline & & $\mathrm{F}_{2}$ & $2.76 \mathrm{c}$ & $2.43 b$ & $15.75 b$ & $12.83 b$ \\
\hline & & $\mathrm{F}_{3}$ & $3.04 \mathrm{a}$ & $2.89 a$ & $18.17 \mathrm{a}$ & $15.25 \mathrm{a}$ \\
\hline & & $\mathrm{F}_{4}$ & $3.05 \mathrm{a}$ & $2.95 \mathrm{a}$ & $18.17 \mathrm{a}$ & $15.67 \mathrm{a}$ \\
\hline \multirow[t]{2}{*}{ Calcareous } & $\mathrm{T}_{1}$ & & $2.52 \mathrm{~d}$ & $2.36 \mathrm{c}$ & $15.67 \mathrm{~b}$ & $13.08 \mathrm{~b}$ \\
\hline & $\mathrm{T}_{0}$ & & $2.74 \mathrm{c}$ & $2.62 b$ & $15.58 b$ & $13.00 \mathrm{~b}$ \\
\hline \multirow[t]{2}{*}{ Clay } & $\mathrm{T}_{1}$ & & $3.17 \mathrm{~b}$ & $2.73 b$ & $18.83 \mathrm{a}$ & $15.08 \mathrm{a}$ \\
\hline & $\mathrm{T}_{0}$ & & $3.29 \mathrm{a}$ & $3.06 \mathrm{a}$ & $18.17 \mathrm{a}$ & $15.67 \mathrm{a}$ \\
\hline
\end{tabular}




\begin{tabular}{|c|c|c|c|c|c|c|}
\hline \multicolumn{7}{|c|}{ Cont. Table 2.} \\
\hline \multirow{4}{*}{ Soil type } & \multicolumn{2}{|c|}{ Treatments } & \multirow{2}{*}{\multicolumn{2}{|c|}{ Plant height (m) }} & \multirow{2}{*}{\multicolumn{2}{|c|}{ No. of branches/ plant }} \\
\hline & \multirow{3}{*}{ Trimming } & \multirow{3}{*}{$\begin{array}{c}\text { Fertilization } \\
\text { treatments }\end{array}$} & & & & \\
\hline & & & \multicolumn{4}{|c|}{ Seasons } \\
\hline & & & 2016 & 2017 & 2016 & 2017 \\
\hline \multirow[t]{4}{*}{ Calcareous } & & $\mathrm{F}_{1}$ & $2.51 \mathrm{e}$ & $2.37 \mathrm{c}$ & $14.83 \mathrm{c}$ & $11.83 \mathrm{c}$ \\
\hline & & $\mathrm{F}_{2}$ & $2.37 f$ & $2.24 \mathrm{c}$ & $14.33 \mathrm{c}$ & $11.67 \mathrm{c}$ \\
\hline & & $\mathrm{F}_{3}$ & $2.82 \mathrm{~d}$ & $2.65 b$ & $16.67 \mathrm{~b}$ & $14.17 \mathrm{~b}$ \\
\hline & & $\mathrm{F}_{4}$ & $2.83 \mathrm{~d}$ & $2.70 \mathrm{~b}$ & $16.67 \mathrm{~b}$ & $14.50 \mathrm{~b}$ \\
\hline \multirow[t]{12}{*}{ Clay } & & $\mathrm{F}_{1}$ & $3.22 b$ & $2.62 b$ & $17.50 \mathrm{~b}$ & $14.33 b$ \\
\hline & & $\mathrm{F}_{2}$ & $3.16 \mathrm{c}$ & $2.62 b$ & $17.17 \mathrm{~b}$ & $14.00 \mathrm{~b}$ \\
\hline & & $\mathrm{F}_{3}$ & $3.27 \mathrm{a}$ & $3.13 \mathrm{a}$ & $19.67 \mathrm{a}$ & $16.33 \mathrm{a}$ \\
\hline & & $\mathrm{F}_{4}$ & $3.28 \mathrm{a}$ & $3.21 \mathrm{a}$ & $19.67 \mathrm{a}$ & $16.83 a$ \\
\hline & $\mathrm{T}_{1}$ & $\mathrm{~F}_{1}$ & $2.77 \mathrm{~d}$ & $2.25 \mathrm{~d}$ & $16.33 b$ & $13.17 \mathrm{~b}$ \\
\hline & & $\mathrm{F}_{2}$ & $2.67 \mathrm{e}$ & $2.35 \mathrm{~cd}$ & $16.17 \mathrm{~b}$ & $13.17 \mathrm{~b}$ \\
\hline & & $\mathrm{F}_{3}$ & $2.97 \mathrm{~b}$ & $2.75 b$ & $18.33 \mathrm{a}$ & $15.33 \mathrm{a}$ \\
\hline & & $\mathrm{F}_{4}$ & $2.97 b$ & $2.82 b$ & $18.17 \mathrm{a}$ & $15.83 \mathrm{a}$ \\
\hline & $\mathrm{T}_{0}$ & $\mathrm{~F}_{1}$ & $2.96 \mathrm{~b}$ & $2.74 \mathrm{~b}$ & $16.00 \mathrm{~b}$ & $13.00 \mathrm{~b}$ \\
\hline & & $\mathrm{F}_{2}$ & $2.86 \mathrm{c}$ & $2.50 \mathrm{c}$ & $15.33 b$ & $12.50 \mathrm{~b}$ \\
\hline & & $\mathrm{F}_{3}$ & $3.12 \mathrm{a}$ & $3.03 \mathrm{a}$ & $18.00 \mathrm{a}$ & $15.17 \mathrm{a}$ \\
\hline & & $\mathrm{F}_{4}$ & $3.13 \mathrm{a}$ & $3.09 \mathrm{a}$ & $18.17 \mathrm{a}$ & $15.50 \mathrm{a}$ \\
\hline \multirow[t]{4}{*}{ Calcareous } & $\mathrm{T}_{1}$ & $\mathrm{~F}_{1}$ & $2.37 \mathrm{i}$ & $2.20 \mathrm{hi}$ & $15.00 \mathrm{def}$ & $12.00 \mathrm{~d}$ \\
\hline & & $\mathrm{F}_{2}$ & $2.23 \mathrm{j}$ & $2.17 \mathrm{i}$ & $14.67 \mathrm{ef}$ & $12.00 \mathrm{~d}$ \\
\hline & & $\mathrm{F}_{3}$ & $2.73 \mathrm{f}$ & 2.50fgh & $16.67 \mathrm{~cd}$ & $14.00 \mathrm{c}$ \\
\hline & & $\mathrm{F}_{4}$ & $2.75 \mathrm{f}$ & $2.57 \mathrm{efg}$ & $16.33 \mathrm{cde}$ & $14.33 \mathrm{c}$ \\
\hline \multirow[t]{4}{*}{ Calcareous } & $\mathrm{T}_{0}$ & $\mathrm{~F}_{1}$ & $2.66 \mathrm{~g}$ & $2.54 \mathrm{efg}$ & $14.67 \mathrm{ef}$ & $11.67 \mathrm{~d}$ \\
\hline & & $\mathrm{F}_{2}$ & $2.51 \mathrm{~h}$ & $2.31 \mathrm{ghi}$ & $14.00 \mathrm{f}$ & $11.33 \mathrm{~d}$ \\
\hline & & $\mathrm{F}_{3}$ & $2.90 \mathrm{e}$ & $2.80 \mathrm{cdef}$ & $16.67 \mathrm{~cd}$ & $14.33 c$ \\
\hline & & $\mathrm{F}_{4}$ & $2.91 \mathrm{e}$ & $2.83 \mathrm{cde}$ & $17.00 \mathrm{c}$ & $14.67 b c$ \\
\hline \multirow[t]{4}{*}{ Clay } & $\mathrm{T}_{1}$ & $\mathrm{~F}_{1}$ & $3.17 \mathrm{~cd}$ & 2.30ghi & $17.67 \mathrm{bc}$ & $14.33 \mathrm{c}$ \\
\hline & & $\mathrm{F}_{2}$ & $3.11 \mathrm{~d}$ & $2.53 \mathrm{efg}$ & $17.67 \mathrm{bc}$ & $14.33 c$ \\
\hline & & $\mathrm{F}_{3}$ & $3.20 \mathrm{bc}$ & $3.00 \mathrm{bc}$ & $20.00 \mathrm{a}$ & $16.67 \mathrm{a}$ \\
\hline & & $\mathrm{F}_{4}$ & $3.20 \mathrm{bc}$ & $3.07 \mathrm{abc}$ & $20.00 \mathrm{a}$ & $17.33 \mathrm{a}$ \\
\hline \multirow[t]{4}{*}{ Clay } & $\mathrm{T}_{0}$ & $\mathrm{~F}_{1}$ & $3.26 \mathrm{~b}$ & $2.93 \mathrm{~cd}$ & $17.33 \mathrm{c}$ & $14.33 c$ \\
\hline & & $\mathrm{F}_{2}$ & $3.20 \mathrm{bc}$ & $2.70 \mathrm{def}$ & $16.67 \mathrm{~cd}$ & $13.67 \mathrm{c}$ \\
\hline & & $\mathrm{F}_{3}$ & $3.35 \mathrm{a}$ & $3.26 \mathrm{ab}$ & $19.33 \mathrm{ab}$ & $16.00 \mathrm{ab}$ \\
\hline & & $\mathrm{F}_{4}$ & $3.36 \mathrm{a}$ & $3.35 \mathrm{a}$ & $19.33 \mathrm{ab}$ & $16.33 \mathrm{a}$ \\
\hline
\end{tabular}

* Values marked with the same alphabetical letter (s), within a comparable group of means, are not significantly different, using L.S.D. test at $\mathrm{P}=0.05$ level.

\section{Productivity and its component characters}

Effects of soil types on yield and yield component characters

The results of Table (3) showed that soil types had positively significant effects on number of tubers / plant and tubers' yield / feddan traits during the two seasons. The data regarding average tuber weight appeared that this trait affected with soil types only during the second season. The obtained data showed that cultivation of
Jerusalem artichoke tubers in clay soil resulted in a significant increase in the number of tubers per plant and the tubers' yield / feddan compared to the cultivation in calcareous soil. There was no significant effect of the soil type treatment on the maturity of Jerusalem artichoke plants.

Effects of trimming treatments on yield and yield component characters

Generally, un-trimming treatment significantly possessed positive effects on tubers' yield /feddan trait 
and its component character (number of tubers / plant) during the two seasons (Table, 3). There were no significant effects of trimming treatments on the average tuber weight character during the second season or on the maturity trait during the two seasons. Gonzales, et al. (1977) reported that topping reduced sweet potato tuber yields; where, the highest production was obtained with no topping. Olasantan and Salaua (2007) illustrated through their experience on okra plants that quarter or half pruning from the upper parts of the main stems of apically debudded plants to stimulate the plants to produce high yielding. The results of Suleiman and Alhaji (2015) revealed that the highest yield of okra and the largest number and weight of pods was produced from growing point pinching comparing with the without pinching.

\section{Effects of fertilization treatments on yield and yield component characters}

As for number of tubers / plant and tubers' yield / feddan traits, the results of Table (3) clearly demonstrated the superiority of the two fertilization treatments $F_{3}$ and $F_{4}$ to the rest of the tested fertilization treatments during the two seasons of this study. The same two fertilization treatments also surpassed the rest of the fertilization treatments during the first season for the average tuber weight (Table, 3). There were no significant differences between the tested fertilization treatments for the average tuber weight during the second season or on the maturity trait during the two seasons. Dorrell and Chubey (1977) found moderate or no yield increases due to increasing nutrient supply. In spite of the huge additions of chemical fertilizers to the cultivated soil in Egypt, the available nutrients level for plants is usually low, since it is rapidly converted to an unavailable form by its reaction with other soil constituents and conditions and becomes inaccessible by plants (El-Dahtory et al., 1989). Nitrogen is an essential element for plant growth and development.

\section{Effects of interactions on yield and yield component characters}

The data of the interaction soil types $\mathrm{x}$ trimming treatments (Table, 3 ) cleared that the interaction (clay $\mathrm{x}$ $\mathrm{T}_{0}$ ) significantly possessed the highest mean value for both tubers' number / plant and tubers' yield / feddan during the two seasons. Average tuber weight character significantly affected with the interaction between soil type $\mathrm{x}$ trimming treatments during the two seasons; where, the interactions (calcareous $\mathrm{x} \mathrm{T}_{0}$ ) and (clay $\mathrm{x} \mathrm{T}_{0}$ ) significantly gave the highest mean values for average tuber weight character during the first season. The data of the second season appeared that the interaction (clay $\mathrm{x} \mathrm{T}_{1}$ ) significantly gave the highest mean value for the average tuber weight without significant differences with the interaction (clay $x \mathrm{~T}_{0}$ ). As for the interactions soil types $\mathrm{x}$ fertilization treatments, the data of Table (3) showed that the two interactions (clay $\mathrm{x} \mathrm{F}_{3}$ ) and (clay $\mathrm{x}$ $\mathrm{F}_{4}$ ) significantly possessed the highest mean values for the number of tubers / plant and tubers' yield / feddan through the two seasons. In terms of the first season for the average tuber weight character, the obtained data indicated that there were not significant differences among the tested interactions except for the interaction (calcareous $\times \mathrm{F}_{2}$ ) (calcareous $\times \mathrm{F}_{4}$ ) which significantly gave the lowest value in this respect. Each of the following interactions; (calcareous $\mathrm{x} \mathrm{F}_{1}$ ), (calcareous $\mathrm{x}$ $F_{2}$ ), (clay $\times F_{1}$ ), (clay $\times F_{3}$ ) and (clay $\times F_{4}$ ), showed highest mean values for the average tuber weight character. The data of the interaction trimming treatments $\mathrm{x}$ fertilization treatments (Table, 3) showed that the interaction $\left(\mathrm{T}_{0} \times \mathrm{F}_{3}\right)$ and $\left(\mathrm{T}_{0} \times \mathrm{F}_{4}\right)$ significantly gave the highest mean values for number of tubers / plant and tubers' yield / feddan traits during the two seasons. The data of the first season appeared that the interactions included the un-trimming treatment significantly gave highest mean values for the average tuber weight compared with the interactions included trimming treatment (Table, 3). As for the second season, the obtained data showed that the interaction $\left(\mathrm{T}_{1}\right.$ $\mathrm{x}_{2}$ ) possessed the highest mean value for the average tuber weight character without significant differences with the interactions $\left(T_{1} \times F_{1}\right),\left(T_{1} \times F_{3}\right),\left(T_{0} \times F_{4}\right),\left(T_{0} \times\right.$ $\left.\mathrm{F}_{1}\right),\left(\mathrm{T}_{0} \times \mathrm{F}_{3}\right)$ and $\left(\mathrm{T}_{0} \times \mathrm{F}_{4}\right)$. The data of the interaction soil types $\mathrm{x}$ trimming treatments $\mathrm{x}$ fertilization treatments showed significant differences for tuber yield I feddan and the studied component characters (number of tubers / plant and average tuber weight) during the two seasons (Table, 3). As for number of tubers / plant character, the results of the two seasons showed that the

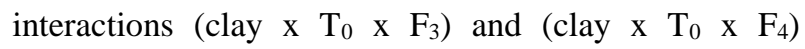
possessed the highest mean values in this respect. Similar results were also obtained regarding the average tuber weight character during the first season, where, the two interactions (clay $\times \mathrm{T}_{0} \times \mathrm{F}_{3}$ ) and (clay $\mathrm{x} \mathrm{T}_{0} \times \mathrm{F}_{4}$ ) significantly gave the highest mean values. The results of the second season showed that the interaction (clay $\mathrm{x}$ $\mathrm{T}_{1} \times \mathrm{F}_{4}$ ) gave the highest mean value without significant differences with the interactions (calcareous $\times \mathrm{T}_{1} \mathrm{x} \mathrm{F}_{2}$ ), (clay $\times \mathrm{T}_{1} \times \mathrm{F}_{1}$ ), (clay $\times \mathrm{T}_{1} \times \mathrm{F}_{3}$ ), (clay $\times \mathrm{T}_{0} \times \mathrm{F}_{1}$ ) and (clay $\times \mathrm{T}_{0} \times \mathrm{F}_{3}$ ). As shown from Table (3), the data of tubers' yield / feddan showed that the two interactions (clay $\times \mathrm{T}_{0} \times \mathrm{F}_{3}$ ) and (clay $\mathrm{x} \mathrm{T}_{0} \times \mathrm{F}_{4}$ ) possessed the highest mean values during the two seasons of this study. It was clear from Table (3) that the maturity trait was not significantly affected by any of the studied interactions during the two study seasons. Generally, it was observed through the previous results especially for tubers' yield / feddan and number of tubers / plant traits 
Table 3. Mean performances of tubers' yield and its component characters of Jerusalem artichoke plants during the seasons of 2016 and 2017

\begin{tabular}{|c|c|c|c|c|c|c|c|c|c|c|}
\hline \multicolumn{3}{|c|}{ Treatments } & \multirow[b]{2}{*}{$\begin{array}{c}\text { No. of } \\
\text { tubers/plant }\end{array}$} & \multirow[b]{2}{*}{$\begin{array}{c}\text { No. of } \\
\text { tubers/plant }\end{array}$} & \multirow{2}{*}{$\begin{array}{c}\text { Average } \\
\text { tuber weight } \\
\text { (g) }\end{array}$} & \multirow{2}{*}{$\begin{array}{c}\text { Average } \\
\text { tuber weight } \\
(\mathrm{g})\end{array}$} & \multirow{2}{*}{$\begin{array}{c}\text { Tubers' } \\
\text { yield } \\
\text { (ton/Fed.) }\end{array}$} & \multirow{2}{*}{$\begin{array}{c}\text { Tubers' } \\
\text { yield } \\
\text { (ton/Fed.) }\end{array}$} & \multirow{2}{*}{$\begin{array}{c}\text { Maturity } \\
\text { (days) }\end{array}$} & \multirow{2}{*}{$\begin{array}{c}\text { Maturity } \\
\text { (days) }\end{array}$} \\
\hline Soil type & Trimming & $\begin{array}{l}\text { Fertilization } \\
\text { treatments }\end{array}$ & & & & & & & & \\
\hline & & & \multicolumn{8}{|c|}{ Seasons } \\
\hline & & & 2016 & 2017 & 2016 & 2017 & 2016 & 2017 & 2016 & 2017 \\
\hline Calcareous & & & $135.13 b^{*}$ & $113.17 b$ & $57.23 \mathrm{a}$ & $49.06 \mathrm{~b}$ & $30.97 b$ & $22.10 b$ & $243.83 a$ & $243.79 a$ \\
\hline \multirow[t]{7}{*}{ Clay } & & & $157.50 \mathrm{a}$ & $138.08 \mathrm{a}$ & $57.74 a$ & $51.21 \mathrm{a}$ & $36.40 \mathrm{a}$ & $28.27 \mathrm{a}$ & $243.87 \mathrm{a}$ & $243.83 a$ \\
\hline & $\mathrm{T}_{1}$ & & $141.79 b$ & $118.38 b$ & $55.94 \mathrm{~b}$ & $50.48 \mathrm{a}$ & $31.73 b$ & $23.88 b$ & $243.71 \mathrm{a}$ & $243.63 \mathrm{a}$ \\
\hline & $\mathrm{T}_{0}$ & & $150.83 \mathrm{a}$ & $132.88 \mathrm{a}$ & $59.04 a$ & $49.79 a$ & $35.63 a$ & $26.48 \mathrm{a}$ & $244.00 \mathrm{a}$ & $244.00 \mathrm{a}$ \\
\hline & & $\mathrm{F}_{1}$ & $143.67 b$ & $121.67 \mathrm{~b}$ & $57.58 \mathrm{ab}$ & $50.68 \mathrm{a}$ & $33.10 \mathrm{~b}$ & $24.67 b$ & $244.00 \mathrm{a}$ & $244.00 \mathrm{a}$ \\
\hline & & $\mathrm{F}_{2}$ & $141.00 \mathrm{~b}$ & $116.67 \mathrm{c}$ & $56.79 b$ & $49.96 a$ & $32.10 \mathrm{c}$ & $23.13 c$ & $244.00 \mathrm{a}$ & $244.00 \mathrm{a}$ \\
\hline & & $\mathrm{F}_{3}$ & $149.92 \mathrm{a}$ & $131.08 \mathrm{a}$ & $57.88 \mathrm{a}$ & $49.93 a$ & $34.73 \mathrm{a}$ & $26.27 \mathrm{a}$ & $243.67 \mathrm{a}$ & $243.67 \mathrm{a}$ \\
\hline & & $\mathrm{F}_{4}$ & $150.67 \mathrm{a}$ & $133.08 \mathrm{a}$ & $57.69 a$ & $49.96 \mathrm{a}$ & $34.80 \mathrm{a}$ & $26.67 \mathrm{a}$ & $243.75 a$ & $243.58 \mathrm{a}$ \\
\hline \multirow[t]{2}{*}{ Calcareous } & $\mathrm{T}_{1}$ & & $130.67 d$ & $104.08 d$ & $55.78 b$ & $48.92 b$ & $29.16 d$ & $20.01 d$ & $243.67 \mathrm{a}$ & $243.58 \mathrm{a}$ \\
\hline & $\mathrm{T}_{0}$ & & $139.58 \mathrm{c}$ & $122.25 \mathrm{c}$ & $58.68 \mathrm{a}$ & $49.21 b$ & $32.76 \mathrm{c}$ & $24.08 \mathrm{c}$ & $244.00 \mathrm{a}$ & $244.00 \mathrm{a}$ \\
\hline \multirow[t]{2}{*}{ Clay } & $\mathrm{T}_{1}$ & & $152.92 b$ & $132.67 b$ & $56.09 b$ & $52.04 \mathrm{a}$ & $34.32 b$ & $27.64 b$ & $243.75 a$ & $243.67 \mathrm{a}$ \\
\hline & $\mathrm{T}_{0}$ & & $162.08 \mathrm{a}$ & $143.50 \mathrm{a}$ & $59.39 a$ & $50.38 \mathrm{ab}$ & $38.52 \mathrm{a}$ & $28.92 \mathrm{a}$ & $244.00 \mathrm{a}$ & $244.00 \mathrm{a}$ \\
\hline \multirow[t]{4}{*}{ Calcareous } & & $\mathrm{F}_{1}$ & $131.17 \mathrm{e}$ & $108.33 \mathrm{e}$ & $57.66 \mathrm{a}$ & $50.00 \mathrm{abc}$ & $30.28 d$ & $21.60 \mathrm{e}$ & $244.00 \mathrm{a}$ & $244.00 \mathrm{a}$ \\
\hline & & $\mathrm{F}_{2}$ & $129.83 \mathrm{e}$ & $100.17 f$ & $55.78 b$ & 51.09ab & $29.00 \mathrm{e}$ & $20.28 f$ & $244.00 \mathrm{a}$ & $244.00 \mathrm{a}$ \\
\hline & & $\mathrm{F}_{3}$ & $139.00 \mathrm{~d}$ & $120.17 d$ & $57.88 \mathrm{a}$ & $47.76 \mathrm{c}$ & $32.20 \mathrm{c}$ & $23.00 \mathrm{~d}$ & $243.67 \mathrm{a}$ & $243.67 \mathrm{a}$ \\
\hline & & $\mathrm{F}_{4}$ & $140.50 \mathrm{~d}$ & $124.00 \mathrm{c}$ & $57.62 \mathrm{a}$ & $47.40 \mathrm{c}$ & $32.40 \mathrm{c}$ & $23.52 d$ & $243.67 \mathrm{a}$ & $243.50 \mathrm{a}$ \\
\hline \multirow[t]{12}{*}{ Clay } & & $\mathrm{F}_{1}$ & $156.17 b$ & $135.00 \mathrm{~b}$ & $57.50 \mathrm{a}$ & $51.37 \mathrm{ab}$ & $35.92 b$ & $27.72 b$ & $244.00 \mathrm{a}$ & $244.00 \mathrm{a}$ \\
\hline & & $\mathrm{F}_{2}$ & $152.17 \mathrm{c}$ & $133.17 b$ & $57.80 \mathrm{a}$ & $48.84 b c$ & $35.20 \mathrm{~b}$ & $26.00 \mathrm{c}$ & $244.00 \mathrm{a}$ & $244.00 \mathrm{a}$ \\
\hline & & $\mathrm{F}_{3}$ & $160.83 a$ & $142.00 \mathrm{a}$ & $57.88 \mathrm{a}$ & $52.10 \mathrm{a}$ & $37.28 \mathrm{a}$ & $31.32 \mathrm{a}$ & $243.67 \mathrm{a}$ & $243.67 \mathrm{a}$ \\
\hline & & $\mathrm{F}_{4}$ & $160.83 a$ & $142.17 \mathrm{a}$ & $57.76 \mathrm{a}$ & $52.52 \mathrm{a}$ & $37.20 \mathrm{a}$ & $29.92 \mathrm{a}$ & $243.83 \mathrm{a}$ & $243.67 \mathrm{a}$ \\
\hline & $\mathrm{T}_{1}$ & $\mathrm{~F}_{1}$ & $139.00 \mathrm{~d}$ & $114.50 \mathrm{c}$ & $56.62 b$ & $50.98 \mathrm{ab}$ & $31.48 \mathrm{~d}$ & $23.32 \mathrm{~d}$ & $244.00 \mathrm{a}$ & $244.00 \mathrm{a}$ \\
\hline & & $\mathrm{F}_{2}$ & $137.83 \mathrm{~d}$ & $105.50 \mathrm{~d}$ & $54.31 \mathrm{c}$ & $51.44 \mathrm{a}$ & $30.00 \mathrm{e}$ & $21.48 \mathrm{e}$ & $244.00 \mathrm{a}$ & $244.00 \mathrm{a}$ \\
\hline & & $\mathrm{F}_{3}$ & $144.83 b c$ & $125.17 b$ & $56.65 b$ & 49.50ab & $32.80 \mathrm{c}$ & $24.92 \mathrm{c}$ & $243.33 a$ & $243.33 \mathrm{a}$ \\
\hline & & $\mathrm{F}_{4}$ & $145.50 \mathrm{bc}$ & $128.33 b$ & $56.17 b$ & 49.98ab & $32.68 \mathrm{c}$ & $25.80 \mathrm{~b}$ & $243.50 \mathrm{a}$ & $243.17 \mathrm{a}$ \\
\hline & $\mathrm{T}_{0}$ & $\mathrm{~F}_{1}$ & $148.33 b$ & $128.83 b$ & $58.54 \mathrm{a}$ & $50.38 \mathrm{ab}$ & $34.72 b$ & $26.00 \mathrm{~b}$ & $244.00 \mathrm{a}$ & $244.00 \mathrm{a}$ \\
\hline & & $\mathrm{F}_{2}$ & $144.17 \mathrm{c}$ & $127.83 \mathrm{~b}$ & $59.27 \mathrm{a}$ & $48.49 b$ & $34.20 \mathrm{~b}$ & $24.80 \mathrm{c}$ & $244.00 \mathrm{a}$ & $244.00 \mathrm{a}$ \\
\hline & & $\mathrm{F}_{3}$ & $155.00 \mathrm{a}$ & $137.00 \mathrm{a}$ & $59.12 \mathrm{a}$ & $50.036 \mathrm{ab}$ & $36.68 \mathrm{a}$ & $27.60 \mathrm{a}$ & $244.00 \mathrm{a}$ & $244.00 \mathrm{a}$ \\
\hline & & $\mathrm{F}_{4}$ & $155.83 \mathrm{a}$ & $137.83 \mathrm{a}$ & $59.21 \mathrm{a}$ & $49.94 \mathrm{ab}$ & $36.92 \mathrm{a}$ & $27.52 \mathrm{a}$ & $244.00 \mathrm{a}$ & $244.00 \mathrm{a}$ \\
\hline
\end{tabular}


Cont. Table 3.

\begin{tabular}{|c|c|c|c|c|c|c|c|c|c|c|}
\hline \multicolumn{3}{|c|}{ Treatments } & \multirow[b]{2}{*}{$\begin{array}{c}\text { No. of } \\
\text { tubers/plant }\end{array}$} & \multirow[b]{2}{*}{$\begin{array}{c}\text { No. of } \\
\text { tubers/plant }\end{array}$} & \multirow{2}{*}{$\begin{array}{c}\text { Average } \\
\text { tuber weight } \\
(\mathrm{g})\end{array}$} & \multirow{2}{*}{$\begin{array}{c}\text { Average } \\
\text { tuber weight } \\
(\mathrm{g})\end{array}$} & \multirow{2}{*}{$\begin{array}{c}\text { Tubers' } \\
\text { yield } \\
\text { (ton/Fed.) }\end{array}$} & \multirow{2}{*}{$\begin{array}{c}\text { Tubers' } \\
\text { yield } \\
\text { (ton/Fed.) }\end{array}$} & \multirow[b]{2}{*}{$\begin{array}{c}\text { Maturity } \\
\text { (days) }\end{array}$} & \multirow[b]{2}{*}{$\begin{array}{c}\text { Maturity } \\
\text { (days) }\end{array}$} \\
\hline Soil type & Trimming & $\begin{array}{l}\text { Fertilization } \\
\text { treatments }\end{array}$ & & & & & & & & \\
\hline & & & \multicolumn{8}{|c|}{ Seasons } \\
\hline & & & 2016 & 2017 & 2016 & 2017 & 2016 & 2017 & 2016 & 2017 \\
\hline \multirow[t]{4}{*}{ Calcareous } & $T_{1}$ & $F_{1}$ & $126.33 \mathrm{~h}$ & $98.00 \mathrm{~g}$ & $56.74 c$ & $50.80 \mathrm{bcd}$ & $28.68 \mathrm{~h}$ & $19.88 \mathrm{~h}$ & $244.00 \mathrm{a}$ & $244.00 \mathrm{a}$ \\
\hline & & $F_{2}$ & $126.67 \mathrm{~h}$ & $84.33 \mathrm{~h}$ & $52.91 \mathrm{~d}$ & 53.89ab & $26.80 \mathrm{i}$ & $18.12 \mathrm{i}$ & $244.00 \mathrm{a}$ & $244.00 \mathrm{a}$ \\
\hline & & $F_{3}$ & $134.00 \mathrm{~g}$ & $113.00 \mathrm{f}$ & $56.97 \mathrm{bc}$ & $46.05 \mathrm{ef}$ & $30.52 \mathrm{~g}$ & $20.80 \mathrm{gh}$ & $243.33 a$ & $243.33 \mathrm{a}$ \\
\hline & & $\mathrm{F}_{4}$ & $135.67 \mathrm{~g}$ & $121.00 \mathrm{e}$ & $56.51 \mathrm{c}$ & $44.92 \mathrm{f}$ & $30.68 \mathrm{~g}$ & $21.72 \mathrm{fg}$ & $243.33 a$ & $243.00 \mathrm{a}$ \\
\hline \multirow[t]{4}{*}{ Calcareous } & $\mathrm{T}_{0}$ & $F_{1}$ & $136.00 \mathrm{~g}$ & $118.67 \mathrm{e}$ & $58.58 \mathrm{ab}$ & 49.19cde & $31.88 \mathrm{f}$ & $23.32 \mathrm{e}$ & $244.00 \mathrm{a}$ & $244.00 \mathrm{a}$ \\
\hline & & $\mathrm{F}_{2}$ & $133.00 \mathrm{~g}$ & $116.00 \mathrm{ef}$ & $58.65 \mathrm{ab}$ & $48.29 \mathrm{def}$ & $31.20 \mathrm{fg}$ & $22.40 \mathrm{ef}$ & $244.00 \mathrm{a}$ & $244.00 \mathrm{a}$ \\
\hline & & $\mathrm{F}_{3}$ & $144.00 \mathrm{f}$ & $127.33 d$ & $58.79 a$ & $49.47 \mathrm{cde}$ & $33.88 \mathrm{de}$ & $25.20 \mathrm{~d}$ & $244.00 \mathrm{a}$ & $244.00 \mathrm{a}$ \\
\hline & & $\mathrm{F}_{4}$ & $145.33 \mathrm{f}$ & $127.00 \mathrm{~d}$ & $58.72 \mathrm{a}$ & 49.89cde & $34.12 \mathrm{cde}$ & $25.32 d$ & $244.00 \mathrm{a}$ & $244.00 \mathrm{a}$ \\
\hline \multirow[t]{4}{*}{ Clay } & $\mathrm{T}_{1}$ & $F_{1}$ & $151.67 \mathrm{de}$ & $131.00 \mathrm{~cd}$ & $56.50 \mathrm{c}$ & 51.16abcd & $34.28 \mathrm{cde}$ & $38.8 \mathrm{c}$ & $244.00 \mathrm{a}$ & $244.00 \mathrm{a}$ \\
\hline & & $\mathrm{F}_{2}$ & $149.00 \mathrm{ef}$ & $126.67 \mathrm{~d}$ & $55.71 \mathrm{c}$ & 48.99de & $33.20 \mathrm{e}$ & $24.80 \mathrm{~d}$ & $244.00 \mathrm{a}$ & $244.00 \mathrm{a}$ \\
\hline & & $F_{3}$ & $155.67 \mathrm{~cd}$ & $137.33 b$ & $56.32 c$ & $52.94 a b c$ & $35.08 \mathrm{c}$ & 29.08ab & $243.33 a$ & $243.33 \mathrm{a}$ \\
\hline & & $\mathrm{F}_{4}$ & $155.33 \mathrm{~cd}$ & $135.67 b c$ & $55.82 \mathrm{c}$ & $55.04 \mathrm{a}$ & $34.68 \mathrm{~cd}$ & $29.88 \mathrm{a}$ & $243.67 \mathrm{a}$ & $243.33 \mathrm{a}$ \\
\hline \multirow[t]{4}{*}{ Clay } & $\mathrm{T}_{0}$ & $F_{1}$ & $160.67 b c$ & $139.00 \mathrm{~b}$ & $58.51 \mathrm{ab}$ & 51.58abcd & $37.60 \mathrm{~b}$ & $28.68 \mathrm{~b}$ & $244.00 \mathrm{a}$ & $244.00 \mathrm{a}$ \\
\hline & & $\mathrm{F}_{2}$ & $155.33 \mathrm{~cd}$ & $139.67 \mathrm{~b}$ & $59.89 a$ & 48.69def & $37.20 \mathrm{~b}$ & $27.20 \mathrm{c}$ & $244.00 \mathrm{a}$ & $244.00 \mathrm{a}$ \\
\hline & & $\mathrm{F}_{3}$ & $166.00 \mathrm{ab}$ & $146.67 \mathrm{a}$ & $59.44 a$ & 51.25abcd & $39.48 \mathrm{a}$ & $30.00 \mathrm{a}$ & $244.00 \mathrm{a}$ & $244.00 \mathrm{a}$ \\
\hline & & $\mathrm{F}_{4}$ & $166.33 \mathrm{a}$ & $148.67 \mathrm{a}$ & 59.71a & $50.00 \mathrm{bcd}$ & $39.72 \mathrm{a}$ & 29.72ab & $244.00 \mathrm{a}$ & $244.00 \mathrm{a}$ \\
\hline
\end{tabular}


that most of the interactions had trimming process gave negative results compared to the interactions had un-trimming process. These negative results of the trimming treatment on the tubers' yield productivity might be due doing trimming process lately at the end of the vegetative growth stage and beginning the initiation of the flowering stage, which the plants become old and woody. In this context, topping did not positively effect on cotton yield, and was less effective when applied later in the season (Naguib et al., 1987).

\section{Tubers' quality}

\section{Effects of soil types on tubers' quality characters}

As shown from Table (4), all the studied tubers' quality characters significantly affected with soil type differences. The highest mean values were scored when Jerusalem artichoke plants grown under clay soil conditions.

\section{Effects of trimming treatments on tubers' quality characters}

The data of Table (4) showed that un-trimming treatment significantly gave the highest mean values for the quality characteristics; i.e., tubers' dry weight \%, inulin and starch percentages during the two seasons.

\section{Effects of fertilization treatments on tubers' quality characters}

Tubers' dry weight percentage seemed to be affected with the applied fertilization treatments (Table, 4). Fertilization treatment $\mathrm{F}_{4}$ significantly gave the highest mean values for Tubers' dry weight percentage followed with the fertilization treatment $\mathrm{F}_{3}$ across the two seasons. Same trend of results were detected for inulin percentages; where the fertilization treatments $F_{4}$ significantly gave the highest mean values followed with the fertilization treatment $F_{3}$. As for starch percentage; the obtained data appeared that each of the two fertilization treatments $\mathrm{F}_{3}$ and $\mathrm{F}_{4}$ significantly possessed the highest mean values during the two seasons. The results of Tony (2013) showed that use combining biofertilizer and chemical fertilization led to increase of dry weight by $18.1 \%$ when compared to control. Ghoneim (2005) emphasized that inoculation of seed pieces of globe artichoke either with Halex-2 significantly recorded the higher mean values for dry weight and total carbohydrates than those of the un-inoculated control. The obtained results agreed, in general, with those of Sorial et al. (1998), who reported some enhancing effects on dry weight content as a result of inoculation with a bio-fertilizer.

\section{Effects of interactions on tubers' quality characters}

The data of Table (4) generally appeared that the interactions soil types $\mathrm{x}$ trimming treatments were significant for all the studied quality characters during the two seasons. In this respect, the results showed that the interaction (clay $\mathrm{x} \mathrm{T}_{0}$ ) was significantly superior to the other interactions for all the studied quality traits over the two seasons. Same approach of results were also detected for the interaction soil types $\mathrm{x}$ fertilization treatments; where all tested quality traits exhibited significant effects for such interaction across the two seasons. The interaction (clay $\mathrm{x}_{\mathrm{F}}$ ) possessed the highest mean values for all the quality characters without significant differences with the interaction (clay $\mathrm{x} \mathrm{F}_{3}$ ) for dry weight and starch percentages (Table, 4). All of the tested quality characters significantly affected with the interaction trimming treatments $\mathrm{x}$ fertilization treatments; as shown in Table (4). The data of the dry weight percentage showed that the interaction $\left(\mathrm{T}_{0} \times \mathrm{F}_{4}\right)$ gave the highest mean values during the two seasons. There were no significant differences between the interaction $\left(\mathrm{T}_{0} \times \mathrm{T}_{3}\right)$ and $\left(\mathrm{T}_{0} \times \mathrm{F}_{4}\right)$ during the two seasons. It appears from Table (4) that the interaction $\left(T_{0} \times F_{4}\right)$ significantly gave the highest mean values for the inulin percentage across the two seasons. As for starch percentage, the data of Table (4) showed that the interaction $\left(\mathrm{T}_{0} \times \mathrm{F}_{4}\right)$ possessed the highest mean value without significant differences with the interactions $\left(\mathrm{T}_{0}\right.$ $\left.\mathrm{x} \mathrm{T}_{1}\right)$ and $\left(\mathrm{T}_{0} \times \mathrm{T}_{3}\right)$ during the first season. The results of the second season appeared that the two interactions $\left(\mathrm{T}_{0}\right.$ $\left.x T_{3}\right)$ and $\left(T_{0} \times F_{4}\right)$ significantly gave the highest mean values for starch percentage. The data of Table (4) showed that most of the desired results for the quality characteristics have been achieved through the

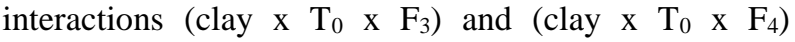
especially for tuber dry weight and starch percentages across the two seasons. As detected from the tested interactions (Table, 4) it is promising to use biostimulants Halex-2 plus yeast extract with a moderate supply level of nitrogen fertilizer ( $75 \mathrm{~kg} \mathrm{~N}$ fed/Fed.) in order to improve Jerusalem artichoke tubers quality characteristics whether the cultivation in clay or calcareous soils. The results of Ezzat et al., (2013) on Jerusalem artichoke plants confirmed that tubers' dry weight and inulin percentages increased with increasing nitrogen rate up to $90 \mathrm{~kg} / \mathrm{Fed}$. In this respect, Sawicka (2002) found that inulin content was the highest in object with adding nitrogen up to $50 \mathrm{~kg} \mathrm{ha}^{-1}$; while tubers' dry weight content increased up to $100 \mathrm{~kg}$ nitrogen $\mathrm{ha}^{-1}$. 
Table 4. Mean performances of tubers' quality characters of Jerusalem artichoke plants during the seasons of 2016 and 2017

\begin{tabular}{|c|c|c|c|c|c|c|c|c|}
\hline \multicolumn{3}{|c|}{ Treatments } & \multirow{2}{*}{$\begin{array}{c}\text { Tubers' } \\
\text { dry } \\
\text { weight } \\
(\%) \\
\end{array}$} & \multirow{2}{*}{$\begin{array}{c}\text { Tubers' } \\
\text { dry } \\
\text { weight } \\
(\%) \\
\end{array}$} & \multirow[b]{2}{*}{$\begin{array}{c}\text { Inulin } \\
(\%)\end{array}$} & \multirow[b]{2}{*}{$\begin{array}{c}\text { Inulin } \\
(\%)\end{array}$} & \multirow[b]{2}{*}{$\begin{array}{c}\text { Starch } \\
(\%)\end{array}$} & \multirow[b]{2}{*}{$\begin{array}{c}\text { Starch } \\
(\%)\end{array}$} \\
\hline Soil type & Trimming & $\begin{array}{c}\text { Fertilization } \\
\text { treatments }\end{array}$ & & & & & & \\
\hline & & & \multicolumn{6}{|c|}{ Seasons } \\
\hline & & & 2016 & 2017 & 2016 & 2017 & 2016 & 2017 \\
\hline Calcareous & & & $20.82 b^{*}$ & $20.35 b$ & $13.45 b$ & $14.58 b$ & $23.54 b$ & $22.10 b$ \\
\hline \multirow[t]{7}{*}{ Clay } & & & $22.96 \mathrm{a}$ & $23.75 \mathrm{a}$ & $14.94 \mathrm{a}$ & $15.75 \mathrm{a}$ & $25.62 \mathrm{a}$ & $25.36 \mathrm{a}$ \\
\hline & $\mathrm{T}_{1}$ & & $20.71 b$ & $21.29 b$ & $13.40 \mathrm{~b}$ & $14.03 b$ & $24.09 \mathrm{~b}$ & $22.88 b$ \\
\hline & $\mathrm{T}_{0}$ & & $23.07 \mathrm{a}$ & $22.81 \mathrm{a}$ & $14.98 \mathrm{a}$ & $16.30 \mathrm{a}$ & $25.07 \mathrm{a}$ & $24.59 \mathrm{a}$ \\
\hline & & $\mathrm{F}_{1}$ & $21.57 \mathrm{c}$ & $21.86 \mathrm{c}$ & $14.08 \mathrm{c}$ & $14.95 \mathrm{c}$ & $24.40 \mathrm{~b}$ & $23.65 b$ \\
\hline & & $\mathrm{F}_{2}$ & $20.38 d$ & $20.96 d$ & $13.44 d$ & $14.17 \mathrm{~d}$ & $23.73 c$ & $22.88 \mathrm{c}$ \\
\hline & & $\mathrm{F}_{3}$ & $22.41 b$ & $22.49 b$ & $14.42 b$ & $15.46 b$ & $25.05 a$ & $24.20 \mathrm{a}$ \\
\hline & & $\mathrm{F}_{4}$ & $23.19 \mathrm{a}$ & $22.90 \mathrm{a}$ & $14.83 \mathrm{a}$ & $16.08 \mathrm{a}$ & $25.14 \mathrm{a}$ & $24.22 \mathrm{a}$ \\
\hline \multirow[t]{2}{*}{ Calcareous } & $\mathrm{T}_{1}$ & & $19.53 \mathrm{c}$ & $19.16 \mathrm{~d}$ & $12.63 \mathrm{c}$ & $13.33 d$ & $23.19 d$ & $21.09 \mathrm{~d}$ \\
\hline & $\mathrm{T}_{0}$ & & $22.09 \mathrm{~b}$ & $21.54 \mathrm{c}$ & $14.27 \mathrm{~b}$ & $15.83 b$ & $23.89 \mathrm{c}$ & $23.12 \mathrm{c}$ \\
\hline \multirow[t]{2}{*}{ Clay } & $\mathrm{T}_{1}$ & & $21.87 b$ & $23.42 b$ & $14.18 b$ & $14.73 c$ & $24.98 b$ & $24.66 b$ \\
\hline & $\mathrm{T}_{0}$ & & $24.04 \mathrm{a}$ & $24.08 \mathrm{a}$ & $15.70 \mathrm{a}$ & $16.78 \mathrm{a}$ & $26.25 \mathrm{a}$ & $26.07 \mathrm{a}$ \\
\hline \multirow[t]{4}{*}{ Calcareous } & & $\mathrm{F}_{1}$ & $20.69 \mathrm{e}$ & $19.91 \mathrm{f}$ & $13.37 \mathrm{~g}$ & $14.40 \mathrm{e}$ & $23.25 \mathrm{e}$ & $22.22 \mathrm{e}$ \\
\hline & & $\mathrm{F}_{2}$ & $19.05 \mathrm{f}$ & $18.86 \mathrm{~g}$ & $12.68 \mathrm{~h}$ & $13.53 \mathrm{f}$ & $22.80 \mathrm{e}$ & $21.17 f$ \\
\hline & & $\mathrm{F}_{3}$ & $21.35 \mathrm{de}$ & $21.00 \mathrm{e}$ & $13.73 f$ & $14.85 \mathrm{~d}$ & $23.91 d$ & $22.60 d$ \\
\hline & & $\mathrm{F}_{4}$ & $22.17 b c$ & $21.63 d$ & $14.02 \mathrm{e}$ & $15.53 c$ & $24.2 \mathrm{~cd}$ & $22.43 \mathrm{de}$ \\
\hline \multirow[t]{12}{*}{ Clay } & & $\mathrm{F}_{1}$ & $22.46 b$ & $23.80 \mathrm{~b}$ & $14.78 \mathrm{c}$ & $15.50 \mathrm{c}$ & $25.55 b$ & $25.09 \mathrm{~b}$ \\
\hline & & $\mathrm{F}_{2}$ & $21.70 \mathrm{~cd}$ & $23.06 \mathrm{c}$ & $14.20 \mathrm{~d}$ & $14.80 \mathrm{~d}$ & $24.65 c$ & $24.58 \mathrm{c}$ \\
\hline & & $\mathrm{F}_{3}$ & $23.47 \mathrm{a}$ & $23.97 \mathrm{ab}$ & $15.12 b$ & $16.07 \mathrm{~b}$ & $26.20 \mathrm{a}$ & $25.79 \mathrm{a}$ \\
\hline & & $\mathrm{F}_{4}$ & $24.20 \mathrm{a}$ & $24.16 \mathrm{a}$ & $15.65 \mathrm{a}$ & $16.63 a$ & $26.07 \mathrm{ab}$ & $26.00 \mathrm{a}$ \\
\hline & $\mathrm{T}_{1}$ & $\mathrm{~F}_{1}$ & $20.19 f$ & $21.04 \mathrm{e}$ & $13.35 \mathrm{~g}$ & $13.67 f$ & $23.83 \mathrm{~d}$ & $22.90 \mathrm{e}$ \\
\hline & & $\mathrm{F}_{2}$ & $19.17 \mathrm{~g}$ & $19.96 f$ & $12.58 \mathrm{~h}$ & $12.90 \mathrm{~g}$ & $23.13 \mathrm{e}$ & $21.98 f$ \\
\hline & & $\mathrm{F}_{3}$ & $21.18 \mathrm{e}$ & $21.96 \mathrm{~d}$ & $13.68 \mathrm{f}$ & $14.45 \mathrm{e}$ & $24.66 \mathrm{bc}$ & $23.36 \mathrm{~d}$ \\
\hline & & $\mathrm{F}_{4}$ & $22.29 \mathrm{~cd}$ & $22.20 \mathrm{~d}$ & $14.00 \mathrm{e}$ & $15.10 \mathrm{~d}$ & $24.73 b c$ & $23.27 \mathrm{de}$ \\
\hline & $\mathrm{T}_{0}$ & $\mathrm{~F}_{1}$ & $22.96 b c$ & $22.67 \mathrm{c}$ & $14.80 \mathrm{c}$ & $16.23 b$ & $24.97 \mathrm{ab}$ & $24.40 \mathrm{~b}$ \\
\hline & & $\mathrm{F}_{2}$ & $21.58 \mathrm{de}$ & $21.95 \mathrm{~d}$ & $14.30 \mathrm{~d}$ & $15.43 \mathrm{c}$ & $24.32 \mathrm{~cd}$ & $23.77 \mathrm{c}$ \\
\hline & & $\mathrm{F}_{3}$ & $23.64 \mathrm{ab}$ & $23.02 b$ & $15.17 b$ & $16.47 b$ & $25.45 \mathrm{a}$ & $25.03 \mathrm{a}$ \\
\hline & & $\mathrm{F}_{4}$ & $24.09 \mathrm{a}$ & $23.60 \mathrm{a}$ & $15.67 \mathrm{a}$ & $17.07 \mathrm{a}$ & $25.55 a$ & $25.17 \mathrm{a}$ \\
\hline \multirow[t]{4}{*}{ Calcareous } & $\mathrm{T}_{1}$ & $\mathrm{~F}_{1}$ & $19.44 \mathrm{~g}$ & $18.57 \mathrm{i}$ & $12.70 \mathrm{~h}$ & $13.00 \mathrm{~g}$ & $22.80 \mathrm{gh}$ & $21.40 \mathrm{~h}$ \\
\hline & & $\mathrm{F}_{2}$ & $17.83 \mathrm{~h}$ & $17.27 \mathrm{j}$ & $11.80 \mathrm{i}$ & $12.20 \mathrm{~h}$ & $22.30 \mathrm{~h}$ & $20.03 \mathrm{i}$ \\
\hline & & $\mathrm{F}_{3}$ & $20.03 \mathrm{fg}$ & $20.22 \mathrm{~h}$ & $12.93 \mathrm{gh}$ & $13.70 \mathrm{f}$ & $23.64 \mathrm{efg}$ & $21.63 \mathrm{~h}$ \\
\hline & & $\mathrm{F}_{4}$ & $20.85 f$ & $20.57 \mathrm{~h}$ & $13.10 \mathrm{~g}$ & $14.43 \mathrm{e}$ & $24.03 \mathrm{def}$ & $21.30 \mathrm{~h}$ \\
\hline \multirow[t]{4}{*}{ Calcareous } & $\mathrm{T}_{0}$ & $F_{1}$ & 21.94de & $21.26 \mathrm{~g}$ & $14.03 \mathrm{e}$ & $15.80 \mathrm{c}$ & $23.70 \mathrm{ef}$ & $23.03 \mathrm{f}$ \\
\hline & & $\mathrm{F}_{2}$ & $20.27 f g$ & $20.45 \mathrm{~h}$ & $13.57 f$ & $14.87 \mathrm{~d}$ & $23.30 \mathrm{fg}$ & $22.30 \mathrm{~g}$ \\
\hline & & $\mathrm{F}_{3}$ & $22.68 \mathrm{~cd}$ & $21.78 f$ & $14.53 \mathrm{~d}$ & $16.00 \mathrm{c}$ & $24.17 \mathrm{def}$ & $23.57 \mathrm{ef}$ \\
\hline & & $\mathrm{F}_{4}$ & $23.49 \mathrm{bc}$ & $22.69 \mathrm{e}$ & $14.93 \mathrm{c}$ & $16.63 b$ & $24.40 \mathrm{de}$ & 23.57ef \\
\hline \multirow[t]{3}{*}{ Clay } & $\mathrm{T}_{1}$ & $F_{1}$ & $20.93 \mathrm{ef}$ & $23.50 \mathrm{~d}$ & $14.00 \mathrm{e}$ & $14.33 \mathrm{e}$ & $24.78 \mathrm{~cd}$ & $24.40 \mathrm{~d}$ \\
\hline & & $\mathrm{F}_{2}$ & $20.50 f$ & $22.66 \mathrm{e}$ & $13.37 f$ & 13.60f & 23.97ef & 23.93de \\
\hline & & $\mathrm{F}_{3}$ & $22.33 \mathrm{~d}$ & $23.70 \mathrm{~cd}$ & $14.43 \mathrm{~d}$ & $15.20 \mathrm{~d}$ & $26.67 \mathrm{bc}$ & $25.08 \mathrm{c}$ \\
\hline
\end{tabular}




\begin{tabular}{|c|c|c|c|c|c|c|c|c|}
\hline \multicolumn{9}{|c|}{ Cont. Table 4.} \\
\hline \multirow{4}{*}{ Soil type } & \multicolumn{2}{|l|}{ Treatments } & \multirow{2}{*}{$\begin{array}{c}\text { Tubers' } \\
\text { dry } \\
\text { weight } \\
(\%)\end{array}$} & \multirow{2}{*}{$\begin{array}{c}\text { Tubers' } \\
\text { dry } \\
\text { weight } \\
(\%)\end{array}$} & \multirow[b]{2}{*}{$\begin{array}{c}\text { Inulin } \\
(\%)\end{array}$} & \multirow[b]{2}{*}{$\begin{array}{c}\text { Inulin } \\
(\%)\end{array}$} & \multirow[b]{2}{*}{$\begin{array}{c}\text { Starch } \\
(\%)\end{array}$} & \multirow[b]{2}{*}{$\begin{array}{c}\text { Starch } \\
(\%)\end{array}$} \\
\hline & Trimming & $\begin{array}{c}\text { Fertilization } \\
\text { treatments }\end{array}$ & & & & & & \\
\hline & & & \multicolumn{6}{|c|}{ Seasons } \\
\hline & & & 2016 & 2017 & 2016 & 2017 & 2016 & 2017 \\
\hline \multirow{5}{*}{ Clay } & & $\mathrm{F}_{4}$ & $23.72 \mathrm{abc}$ & $23.82 \mathrm{bcd}$ & $14.90 \mathrm{c}$ & $15.77 \mathrm{c}$ & $25.43 \mathrm{bc}$ & $25.23 \mathrm{bc}$ \\
\hline & $\mathrm{T}_{0}$ & $F_{1}$ & $23.98 \mathrm{ab}$ & $24.09 \mathrm{abc}$ & $15.57 \mathrm{~b}$ & $16.67 \mathrm{~b}$ & $26.23 \mathrm{ab}$ & $25.77 \mathrm{~b}$ \\
\hline & & $\mathrm{F}_{2}$ & $22.90 \mathrm{~cd}$ & $23.46 \mathrm{~d}$ & $15.03 \mathrm{c}$ & $16.00 \mathrm{c}$ & $25.33 c$ & $25.33 b c$ \\
\hline & & $\mathrm{F}_{3}$ & $24.61 \mathrm{a}$ & $24.25 \mathrm{ab}$ & $15.80 \mathrm{~b}$ & $16.93 b$ & $26.73 \mathrm{a}$ & $26.50 \mathrm{a}$ \\
\hline & & $\mathrm{F}_{4}$ & $24.68 \mathrm{a}$ & $24.50 \mathrm{a}$ & $16.40 \mathrm{a}$ & $17.50 \mathrm{a}$ & $26.70 \mathrm{a}$ & $26.77 \mathrm{a}$ \\
\hline
\end{tabular}

* Values marked with the same alphabetical letter (s), within a comparable group of means, are not significantly different, using L.S.D. test at $\mathrm{P}=0.05$ level.

\section{$\mathrm{N}, \mathrm{P}$ and $\mathrm{K}$ in tubers Effects of soil types on N, P and $K$}

As for the tested main elements, the data of Table (5) showed that soil types showed significant effects on the tested main elements ( $\mathrm{N}, \mathrm{P}$ and $\mathrm{K}$ ) during the two seasons; where clay soil possessed the highest mean values in this respect. These significance differences in the content of the tubers from the available main mineral elements (N, P and $\mathrm{K}$ ) can be attributed to the estimated fundamental differences of these elements in the two soil types (Table, 1).

\section{Effects of trimming treatments on $\mathrm{N}, \mathrm{P}$ and $\mathrm{K}$}

With regard to the applied trimming treatments, it was clear from the results in Table (5) that un-trimming treatment had positive effects on the content of the tubers from the three mineral elements $(\mathrm{N}, \mathrm{P}$ and $\mathrm{K})$ during the two seasons.

\section{Effects of fertilization treatments on N, P and $\mathrm{K}$}

The data of nitrogen content showed that the fertilization treatments $F_{3}$ and $F_{4}$ significantly gave the highest mean values for nitrogen content during the two seasons (Table, 5). Fertilization treatment $F_{2}$ significantly gave the best results for phosphorus content over the two seasons. This result can be attributed to the role of yeast extract in its positive effect on the growth and spread of plant roots, making it more absorbable for phosphorus from the soil. The fertilization treatment $\mathrm{F}_{4}$ significantly gave the highest mean value for tubers' potassium content during the two experimental seasons followed with the fertilization treatments $F_{1}$ and $F_{3}$ (Table, 5). The result of Abdel-Razzak and El-Sharkawy (2013) reflected that inoculated garlic cloves with biofertilizer (Halex-2) increased $\mathrm{K}$ concentration in garlic tissues compared with un-inoculated plants. However, the authors illustrated that concentrations of $\mathrm{N}$ and $\mathrm{P}$ did not reflect any differences.

\section{Effects of interactions on $\mathbf{N}, \mathbf{P}$ and $\mathrm{K}$}

As shown from the Table (5), all studied interactions exhibited significant effects for the studied main element contents $(\mathrm{N}$ and $\mathrm{K})$ during the two seasons. It appears from Table (5) that tubers' phosphorus content did not affect with such interactions. The results presented in Table (5) for the interaction soil types $\mathrm{x}$ trimming treatments indicated that growing Jerusalem artichoke plants in clay soil without trimming significantly increased both $\mathrm{N}$ and $\mathrm{K}$ concentrations in tubers. This result might be owing to that, the un-trimming treatment possessed better results for the vegetative growth parameters, tubers' yield and its component characters, which positively reflected the content of the tubers from the estimated $\mathrm{N}$ and $\mathrm{K}$ mineral elements (Tables 2 and 3 ). The results obtained from Table (5); generally showed the superiority of the clay soil in their interaction with the fertilization treatments compared with the calcareous in relation to the estimated mineral elements. As for nitrogen content, the data showed that the interaction clay $x F_{1}$ and clay $x F_{3}$ significantly gave the highest mean values during the first season; while in the second season, both clay $\mathrm{x}_{3}$ and clay $\mathrm{x} \mathrm{F}_{4}$ superiority over the rest of the interactions. The interaction clay $\mathrm{x} \mathrm{F}_{4}$ significantly gave the highest mean values for tubers content of potassium during the two season of the experimentation. The solubility of nutrients is particularly low and the nutrients deficiencies were often shown on the plants grown on calcareous soils because of high pH (Kacar and Katkat, 2007). The obtained results could be returned that the growing plants take more mineral elements due to the better-developed root systems when planting in clay soil. For the interaction between the trimming treatments and the fertilization treatments, the results of Table (5) showed superiority of the interactions un-trimming $\mathrm{x} \mathrm{F}_{3}$ and un-trimming $\times \mathrm{F}_{4}$ regarding nitrogen and potassium contents, respectively during the two seasons. Tubers 
significantly contained highest mean values of nitrogen through the interactions clay $\times \mathrm{T}_{0} \times \mathrm{F}_{1}$ and clay $\times \mathrm{T}_{0} \times \mathrm{F}_{3}$ during the first season; while the interactions clay $\mathrm{x} \mathrm{T}_{0} \mathrm{x}$ $\mathrm{F}_{3}$ and clay $\mathrm{x} \mathrm{T}_{0} \times \mathrm{F}_{4}$ gave the highest mean values for nitrogen content during the second season (Table, 5). Potassium content results showed superior the interactions clay $\times T_{0} \times F_{1}$ and clay $\times T_{0} \times F_{4}$ on the rest of the tested interactions during the first season. On the other hand, the interaction clay $\times \mathrm{T}_{0} \times \mathrm{F}_{4}$ gave the highest mean value for potassium content during the second season. Generally, In general, the results showed an increase in potassium content through the treatment $100 \mathrm{~kg}$ nitrogen/feddan followed by the treatments containing a mixture of both halex-2 and yeast extract. As for the results of tubers content of phosphorus, the results shown in Table (5) showed the absence of the significant of all studied interactions, although there were clear differences between the treatments within each interaction. This can be attributed to the fact that the results of each of these interactions are in a harmonious direction during the two study seasons. In this respect, phosphorus contents were increased when Jerusalem artichoke plants were grown in clay soil without trimming. Also, phosphorus contents were increased when the plants were grown in clay soil with any of the applied fertilization treatments. In the same context, the superiority of the phosphorus results was shown in the case of non-trimming of the growing plants with any of the fertilization treatments compared to trimming treatment. The results of Ezzat et al., (2013) on Jerusalem artichoke plants showed that increasing nitrogen fertilizers up to $90 \mathrm{~kg} / \mathrm{Fed}$. led to increasing in macro and micronutrients. Finally, it was evident from the results that phosphorus contents were increased when the tubers were planted in clay soil without trimming the growing plants with any of the applied fertilization treatments during the two seasons of the experiment.

Table 5. Mean performances of tubers' $N, P$ and $K$ characters of Jerusalem artichoke plants during the seasons of 2016 and 2017

\begin{tabular}{|c|c|c|c|c|c|c|c|c|}
\hline \multicolumn{3}{|c|}{ Treatments } & \multirow[b]{2}{*}{$\begin{array}{c}\text { Nitrogen } \\
(\%)\end{array}$} & \multirow[b]{2}{*}{$\begin{array}{c}\text { Nitrogen } \\
(\%)\end{array}$} & \multirow[b]{2}{*}{$\begin{array}{c}\text { Phosphoru } \\
\text { s (\%) }\end{array}$} & \multirow[b]{2}{*}{$\begin{array}{c}\text { Phosphoru } \\
\text { s (\%) }\end{array}$} & \multirow[b]{2}{*}{$\begin{array}{c}\text { Potassium } \\
(\%)\end{array}$} & \multirow[b]{2}{*}{$\begin{array}{c}\text { Potassium } \\
(\%)\end{array}$} \\
\hline Soil type & Trimming & $\begin{array}{l}\text { Fertilization } \\
\text { treatments }\end{array}$ & & & & & & \\
\hline & & & \multicolumn{6}{|c|}{ Seasons } \\
\hline & & & 2016 & 2017 & 2016 & 2017 & 2016 & 2017 \\
\hline Calcareous & & & $2.22 \mathrm{~b}^{*}$ & $2.05 \mathrm{~b}$ & $0.32 \mathrm{~b}$ & $0.24 \mathrm{~b}$ & $2.37 \mathrm{~b}$ & $2.12 \mathrm{~b}$ \\
\hline \multirow[t]{7}{*}{ Clay } & & & $3.02 \mathrm{a}$ & $2.87 \mathrm{a}$ & $0.52 \mathrm{a}$ & $0.42 \mathrm{a}$ & $5.05 \mathrm{a}$ & $4.74 \mathrm{a}$ \\
\hline & $\mathrm{T}_{1}$ & & $2.51 \mathrm{~b}$ & $2.30 \mathrm{~b}$ & $0.36 \mathrm{~b}$ & $0.29 \mathrm{~b}$ & $3.45 \mathrm{~b}$ & $3.18 \mathrm{~b}$ \\
\hline & $\mathrm{T}_{0}$ & & $2.74 \mathrm{a}$ & $2.61 \mathrm{a}$ & $0.47 \mathrm{a}$ & $0.37 \mathrm{a}$ & $3.97 \mathrm{a}$ & $3.68 \mathrm{a}$ \\
\hline & & $\mathrm{F}_{1}$ & $2.68 \mathrm{~b}$ & $2.48 \mathrm{~b}$ & $0.38 \mathrm{c}$ & $0.30 \mathrm{c}$ & $3.67 \mathrm{~b}$ & 3. $36 \mathrm{~b}$ \\
\hline & & $\mathrm{F}_{2}$ & $2.25 \mathrm{c}$ & $2.06 \mathrm{c}$ & $0.46 \mathrm{a}$ & $0.37 \mathrm{a}$ & $3.39 \mathrm{c}$ & $3.06 \mathrm{c}$ \\
\hline & & $\mathrm{F}_{3}$ & $2.83 \mathrm{a}$ & $2.64 \mathrm{a}$ & $0.44 \mathrm{~b}$ & $0.35 \mathrm{~b}$ & $3.57 \mathrm{~b}$ & $3.32 \mathrm{~b}$ \\
\hline & & $\mathrm{F}_{4}$ & $2.71 \mathrm{ab}$ & $2.65 \mathrm{a}$ & $0.39 \mathrm{c}$ & $0.30 \mathrm{c}$ & $4.22 \mathrm{a}$ & $3.99 \mathrm{a}$ \\
\hline \multirow[t]{2}{*}{ Calcareous } & $\mathrm{T}_{1}$ & & $2.14 \mathrm{~d}$ & $1.96 \mathrm{~d}$ & $0.27 \mathrm{a}$ & $0.23 \mathrm{a}$ & $2.28 \mathrm{~d}$ & $2.08 \mathrm{c}$ \\
\hline & $\mathrm{T}_{0}$ & & $2.30 \mathrm{c}$ & $2.14 \mathrm{c}$ & $0.36 \mathrm{a}$ & $0.26 \mathrm{a}$ & $2.46 \mathrm{c}$ & $2.16 \mathrm{c}$ \\
\hline \multirow[t]{2}{*}{ Clay } & $\mathrm{T}_{1}$ & & $2.88 \mathrm{~b}$ & $2.65 \mathrm{~b}$ & $0.44 \mathrm{a}$ & $0.35 \mathrm{a}$ & $4.62 \mathrm{~b}$ & $4.28 \mathrm{~b}$ \\
\hline & $\mathrm{T}_{0}$ & & $3.17 \mathrm{a}$ & $3.09 \mathrm{a}$ & $0.59 \mathrm{a}$ & $0.48 \mathrm{a}$ & $5.49 \mathrm{a}$ & $5.21 \mathrm{a}$ \\
\hline \multirow[t]{4}{*}{ Calcareous } & & $\mathrm{F}_{1}$ & $2.25 \mathrm{e}$ & $2.08 \mathrm{e}$ & $0.28 \mathrm{a}$ & $0.22 \mathrm{a}$ & $2.25 \mathrm{e}$ & $2.03 \mathrm{e}$ \\
\hline & & $\mathrm{F}_{2}$ & $1.68 \mathrm{f}$ & $1.47 \mathrm{f}$ & $0.35 \mathrm{a}$ & $0.28 \mathrm{a}$ & $2.02 \mathrm{f}$ & $1.68 \mathrm{f}$ \\
\hline & & $\mathrm{F}_{3}$ & $2.50 \mathrm{~d}$ & $2.33 \mathrm{~d}$ & $0.34 \mathrm{a}$ & $0.26 \mathrm{a}$ & $2.15 \mathrm{ef}$ & $1.92 \mathrm{e}$ \\
\hline & & $\mathrm{F}_{4}$ & $2.45 \mathrm{~d}$ & $2.32 \mathrm{~d}$ & $0.29 \mathrm{a}$ & $0.22 \mathrm{a}$ & $3.05 \mathrm{~d}$ & $2.85 \mathrm{~d}$ \\
\hline \multirow[t]{6}{*}{ Clay } & & $\mathrm{F}_{1}$ & $3.12 \mathrm{ab}$ & $2.88 \mathrm{~b}$ & $0.49 \mathrm{a}$ & $0.39 \mathrm{a}$ & $5.09 \mathrm{~b}$ & $4.68 \mathrm{~b}$ \\
\hline & & $\mathrm{F}_{2}$ & $2.83 \mathrm{c}$ & $2.66 \mathrm{c}$ & $0.57 \mathrm{a}$ & $0.46 \mathrm{a}$ & $4.76 \mathrm{c}$ & $4.43 \mathrm{c}$ \\
\hline & & $\mathrm{F}_{3}$ & $3.17 \mathrm{a}$ & $2.95 \mathrm{ab}$ & $0.54 \mathrm{a}$ & $0.44 \mathrm{a}$ & $4.98 \mathrm{~b}$ & $4.73 \mathrm{~b}$ \\
\hline & & $\mathrm{F}_{4}$ & $2.99 \mathrm{bc}$ & $2.99 \mathrm{a}$ & $0.48 \mathrm{a}$ & $0.38 \mathrm{a}$ & $5.38 \mathrm{a}$ & $5.12 \mathrm{a}$ \\
\hline & $\mathrm{T}_{1}$ & $\mathrm{~F}_{1}$ & $2.58 \mathrm{c}$ & $2.40 \mathrm{c}$ & $0.32 \mathrm{a}$ & $0.26 \mathrm{a}$ & $3.39 \mathrm{e}$ & $3.12 \mathrm{e}$ \\
\hline & & $\mathrm{F}_{2}$ & $2.15 \mathrm{e}$ & $1.93 \mathrm{e}$ & $0.41 \mathrm{a}$ & $0.32 \mathrm{a}$ & $3.07 \mathrm{f}$ & $2.78 \mathrm{f}$ \\
\hline
\end{tabular}




\begin{tabular}{|c|c|c|c|c|c|c|c|c|}
\hline \multicolumn{9}{|c|}{ Cont. Table 5.} \\
\hline \multirow[b]{2}{*}{ Soil type } & \multicolumn{2}{|l|}{ Treatments } & \multirow[b]{2}{*}{$\begin{array}{c}\text { Nitrogen } \\
(\%)\end{array}$} & \multirow[b]{2}{*}{$\begin{array}{c}\text { Nitrogen } \\
(\%)\end{array}$} & \multirow[b]{2}{*}{$\begin{array}{c}\text { Phosphoru } \\
\text { s (\%) }\end{array}$} & \multirow[b]{2}{*}{$\begin{array}{c}\text { Phosphoru } \\
\text { s (\%) }\end{array}$} & \multirow[b]{2}{*}{$\begin{array}{c}\text { Potassium } \\
(\%)\end{array}$} & \multirow[b]{2}{*}{$\begin{array}{c}\text { Potassium } \\
(\%)\end{array}$} \\
\hline & Trimming & $\begin{array}{l}\text { Fertilization } \\
\text { treatments }\end{array}$ & & & & & & \\
\hline & & & \multicolumn{6}{|c|}{ Seasons } \\
\hline & & & 2016 & 2017 & 2016 & 2017 & 2016 & 2017 \\
\hline & & $\mathrm{F}_{3}$ & $2.66 \mathrm{bc}$ & $2.45 \mathrm{c}$ & $0.37 \mathrm{a}$ & $0.30 \mathrm{a}$ & $3.33 \mathrm{e}$ & $3.04 \mathrm{e}$ \\
\hline & & $\mathrm{F}_{4}$ & $2.65 \mathrm{bc}$ & $2.44 \mathrm{c}$ & $0.34 \mathrm{a}$ & $0.27 \mathrm{a}$ & $4.00 \mathrm{~b}$ & $3.78 \mathrm{~b}$ \\
\hline & $\mathrm{T}_{0}$ & $\mathrm{~F}_{1}$ & $2.79 \mathrm{~b}$ & $2.56 \mathrm{~b}$ & $0.45 \mathrm{a}$ & $0.34 \mathrm{a}$ & $3.95 \mathrm{bc}$ & $3.60 \mathrm{c}$ \\
\hline & & $\mathrm{F}_{2}$ & $2.36 \mathrm{~d}$ & $2.20 \mathrm{~d}$ & $0.52 \mathrm{a}$ & $0.42 \mathrm{a}$ & $3.71 \mathrm{~d}$ & $3.33 \mathrm{~d}$ \\
\hline & & $\mathrm{F}_{3}$ & $3.0 \mathrm{a}$ & $2.83 \mathrm{a}$ & $0.50 \mathrm{a}$ & $0.39 \mathrm{a}$ & $3.80 \mathrm{~cd}$ & $3.60 \mathrm{c}$ \\
\hline & & $\mathrm{F}_{4}$ & $2.80 \mathrm{~b}$ & $2.86 \mathrm{a}$ & $0.43 \mathrm{a}$ & $0.32 \mathrm{a}$ & $4.43 \mathrm{a}$ & $4.20 \mathrm{a}$ \\
\hline \multirow[t]{4}{*}{ Calcareous } & $\mathrm{T}_{1}$ & $\mathrm{~F}_{1}$ & $2.21 \mathrm{e}$ & $2.10 \mathrm{f}$ & $0.23 \mathrm{a}$ & $0.19 \mathrm{a}$ & $2.17 \mathrm{~g}$ & $2.07 \mathrm{~g}$ \\
\hline & & $\mathrm{F}_{2}$ & $1.63 \mathrm{f}$ & $1.41 \mathrm{~g}$ & $0.31 \mathrm{a}$ & $0.26 \mathrm{a}$ & $1.80 \mathrm{~h}$ & $1.63 \mathrm{i}$ \\
\hline & & $\mathrm{F}_{3}$ & $2.36 \mathrm{de}$ & $2.17 \mathrm{f}$ & $0.30 \mathrm{a}$ & $0.25 \mathrm{a}$ & $2.13 \mathrm{~g}$ & $1.83 \mathrm{hi}$ \\
\hline & & $\mathrm{F}_{4}$ & $2.34 \mathrm{de}$ & $2.15 \mathrm{f}$ & $0.26 \mathrm{a}$ & $0.22 \mathrm{a}$ & $3.00 \mathrm{f}$ & $2.80 \mathrm{f}$ \\
\hline \multirow[t]{4}{*}{ Calcareous } & $\mathrm{T}_{0}$ & $\mathrm{~F}_{1}$ & $2.30 \mathrm{e}$ & $2.06 \mathrm{f}$ & $0.34 \mathrm{a}$ & $0.24 \mathrm{a}$ & $2.33 \mathrm{~g}$ & $2.00 \mathrm{gh}$ \\
\hline & & $\mathrm{F}_{2}$ & $1.72 \mathrm{f}$ & $1.52 \mathrm{~g}$ & $0.39 \mathrm{a}$ & $0.31 \mathrm{a}$ & $2.24 \mathrm{~g}$ & $1.73 \mathrm{i}$ \\
\hline & & $\mathrm{F}_{3}$ & $2.63 \mathrm{c}$ & $2.48 \mathrm{e}$ & $0.37 \mathrm{a}$ & $0.27 \mathrm{a}$ & $2.17 \mathrm{~g}$ & $2.00 \mathrm{gh}$ \\
\hline & & $\mathrm{F}_{4}$ & $2.57 \mathrm{~cd}$ & $2.49 \mathrm{e}$ & $0.33 \mathrm{a}$ & $0.23 \mathrm{a}$ & $3.10 \mathrm{f}$ & $2.90 \mathrm{f}$ \\
\hline \multirow[t]{4}{*}{ Clay } & $\mathrm{T}_{1}$ & $\mathrm{~F}_{1}$ & $2.95 \mathrm{~b}$ & $2.69 \mathrm{~d}$ & $0.42 \mathrm{a}$ & $0.33 \mathrm{a}$ & $4.60 \mathrm{e}$ & $4.17 \mathrm{~d}$ \\
\hline & & $\mathrm{F}_{2}$ & $2.66 \mathrm{c}$ & $2.45 \mathrm{e}$ & $0.50 \mathrm{a}$ & $0.39 \mathrm{a}$ & $4.35 \mathrm{e}$ & $3.93 \mathrm{e}$ \\
\hline & & $\mathrm{F}_{3}$ & $2.96 \mathrm{~b}$ & $2.72 \mathrm{~d}$ & $0.45 \mathrm{a}$ & $0.35 \mathrm{a}$ & $4.52 \mathrm{e}$ & $4.25 \mathrm{~d}$ \\
\hline & & $\mathrm{F}_{4}$ & $2.95 \mathrm{~b}$ & $2.74 \mathrm{~d}$ & $0.42 \mathrm{a}$ & $0.33 \mathrm{a}$ & $5.00 \mathrm{~d}$ & $4.77 \mathrm{c}$ \\
\hline \multirow[t]{4}{*}{ Clay } & $\mathrm{T}_{0}$ & $\mathrm{~F}_{1}$ & $3.28 \mathrm{a}$ & $3.07 \mathrm{~b}$ & $0.55 \mathrm{a}$ & $0.45 \mathrm{a}$ & $5.57 \mathrm{ab}$ & $5.20 \mathrm{~b}$ \\
\hline & & $\mathrm{F}_{2}$ & $3.00 \mathrm{~b}$ & $2.87 \mathrm{c}$ & $0.64 \mathrm{a}$ & $0.53 \mathrm{a}$ & $5.17 \mathrm{~cd}$ & $4.93 \mathrm{c}$ \\
\hline & & $\mathrm{F}_{3}$ & $3.37 \mathrm{a}$ & $3.18 \mathrm{ab}$ & $0.63 \mathrm{a}$ & $0.52 \mathrm{a}$ & $5.44 \mathrm{bc}$ & $5.20 \mathrm{~b}$ \\
\hline & & $\mathrm{F}_{4}$ & $3.02 \mathrm{~b}$ & $3.23 \mathrm{a}$ & $0.54 \mathrm{a}$ & $0.42 \mathrm{a}$ & $5.76 \mathrm{a}$ & $5.49 \mathrm{a}$ \\
\hline
\end{tabular}

${ }^{*}$ Values marked with the same alphabetical letter (s), within a comparable group of means, are not significantly different, using L.S.D. test at $\mathrm{P}=0.05$ level.

\section{REFERENCES}

A.O.A.C. 1990. Official methods of analysis, $15^{\text {th }}$ Ed., Association of Official Analytical Chemists, Inc.,USA.

Abdel-Razzak, H.S. and G.A. El-Sharkawy. 2013. Effect of biofertilizer and humic acid applications on growth, yield, quality and storability of two garlic (Allium sativum L.) cultivars. Asian J. Crop Sci., 5(1): 48-64.

Ahmed, A.A., M.M.H. Abd El-Baky, M.F. Zaki and F.S. Abd El-Aal. 2011. Effect of foliar application of active yeast extract and zinc on growth, yield and quality of potato plant (Solanum tuberosum L). J. Appl. Sci. Res., 7 (12): 2479-2488.

Al-Obidy, A. F.2011. Effect of pinching and irrigation periods on plant growth and

yield of Hibiscus sabdariffa L. Anbar J. Agric. Sci. 9 (3):2028.

Amara, M.A., S.A. Nasr and K.A. Rabie. 1995. phytohormonal interactions between pseudomonas fluorescens,Rhizobium leguminosarum and Triticumaestivum. Annals Agric. Sci., Ain Shams Univ., Cairo, 40(1): 81-97.
Amer, S.S.A. 2004. Growth, green pods yield and seeds yield of common bean (phaseolusvulgarisL.) affected by active dry yeast, salicylic acid and their interaction. J. Agric. Sci. Mansoura Univ., 29: 1407-1422.

Apte, R. and S.T. Shende. 1981. Studies on Azotobacter chroococcum IV. Seed bacterization with strains of Azotobacter chroococcum and their effect on crop yield. Zbl. Part. 11. 136: 837-640.

Baker, L., P. J. Thomassin and J. C. Henning. 1990. The economic competitiveness of Jerusalem artichoke (Helianthus tuberosus L.) as an agricultural feedstock and ethanol production for transportation fuels. Canad. J. Agric. Econom. 38: 981-990.

Barakat, M.S. and A.H. Abdel-Razik. 1990. Effect of apex removal and gebberellic acid combinations on flowering and yield of tomato. Alex. J. Agric. Res., 35(2): 105-114.

Barnett, J.A., R.W. Payne and D. Yarrow, 1990. Yeasts characteristics and identification. Cambradge. Camb.CBZBR., pp: 999. 
Cacciari, D.L.; T.Pietrosanti and W. Peitrosanti. 1989.Phytohormone-like substances produced by single and mixed diazotrophic cultures of Azospirillum and Arthrobacter. Plant and Soil, 115: 151-153.

Castelfranco, P.A. and S.I. Beale, 1983.Chlorophyll biosynthesis recent advances and areas of current interest.Ann. Rev. Plant Physio., 34: 241-278.

Chapman, H. D. and P.F. Pratt. 1961. Methods of analysis for soil, plant and water. University of California, Division of Agricultural Sciences. Riverside California.

Co-Stat Software. 2004. User's manual version. Cohort Tusson, Arizona, USA.

Dorrell, D.G. and B.B. Chubey.1977. Irrigation fertilizer, harvest dates and storage effects on the reducing sugar and fructose concentration of Jerusalem artichoke tubers. Canadian J. Pl. Sci., 57: 591-596.

El-Assiouty, F.M.M. 1988. Effect of decapitation with presowing seed treatments in some micronutrients on growth, sedd yield and quality of okra. J. Agric. Sci. Mansoura Univ., 23(7): 3371-3349.

El-Dahtory; Th.M., M. Abdel-Nasser, A.R. Abdullah and M.A. El-Mohandes. 1989. Studies on phosphate solubilizing bacteria under different soil amendments. Minia.. Agric. Res. \& Dev. 11(2): 935-950.

El-Ghinbihi, F.H. and F.A. Ali. 2001. Response of some potato cultivars to biofertilizer (Halex 2) and different mineral nitrogen levels. Zagazig J. Agric. Res., 28: 133-162.

Evenhuis, B. and P. W. De Waard. 1980. Principles and practices in plant analysis. FAO. Soils Bull., 38(1): 152163.

Ezzat, A.S., A.A. El-Awady and U.M. Saif Eldeen. 2013. Effect of some cropping practices on growth, yield, quality properties and storability of Jerusalem artichoke. Hortscience J. Suez Canal Univ. 1: 9-17.

FAO. 1977. Calcareous soils. FAO soils bulletin 21, Second printing, http://www.fao.org/3/x5868e/x5868e00.htm\#Contents

Fathy, E.S.L. and S. Farid. 1996. The possibility of using vitamin $\mathrm{B}$ sand yeast to delay senescence and improve growth and yield of common beans (Phaseolus vulgaris. L) J. A gric. Sci. Mansoura Univ., 21(4): 1415-1423.

Fathy, S.S., A.M. Moghasy, M.E. El-Nagar and M.H. Tolba. 2008. Effect of some natural essential oil on cowpea productivity and storability. J. Agric. Sci, Mansoura Univ., 33 (11): 8057-8070.

Fayad, M.H. 2005. Effect of foliar spraying with some plant growth regulators and plant extracts on growth and yield of cucumber plants. Ph. D., Fac., Agric. Basra Univ., Iraq.

Fayez, M., N.F. Emam and H.E. Makboul. 1985. The possible use of nitrogen fixing Azospirilium as biofertilizer for wheat plants. Egypt J. Microbiol., 20: 199-206.

Feleafel, M.N. 2005). Effect of NPK and biofertilizer on vegetative growth, tuber yield and quality of potato. J. Agric. and Env. Sci. 4(2): 96-113.
Ghoneim, I.M. 2000.Effect of okra plants' decapitation under various nitrogen levels on growth, flowering, green pod yield and seed production. J. Adv. Agric. Res., 5(2): 1405-1424.

Ghoneim, I.M. 2005. Effect of biofertilizer types under varying nitrogen levels on vegetative growth, heads yield and quality of globe artichoke (Cynarascolymus, L.). J. Agric. and Env. Sci., 4: 123.

Gonzales, F.R., T.G. Cadiz and M.S. Bugawan. 1977. Effects of topping and fertilization on the yield and protein content of three varieties of sweet potato. Philippine J. Crop Sci. 2 (2): 97-102.

Hassan, H.M., O.K. Ahmed, H.A. El-Shemy and A.S. Afify. 2008. Palm pollen extracts as plant growth substances for banana tissue culture. World J. Agric. Sci., 4(4):514-520.

Kacar, B. and A.V. Katkat. 2007. Plant nutrition. Nobel Publication No: 849. (3 ${ }^{\text {rd }}$ ed.) Science and rd Biology Publication Series 29, Ankara, Turkey.

Khedr, Z.M.A. and S. Farid. 2000. Response of naturally virus infected tomato plants to yeast extract and phosphoric acid application. Annals of Agric. Sci., Moshtohor, 38(2): 927939.

Kocsis, L., P. Liebhard and W. Praznik. 2008. Einfluss des Erntetermins auf Knollengröße und Trockensubstanzgehalt sowie Inulin- und Zuckerertrag bei Topinambursorten unterschiedlicher Reifezeit (Helianthus tuberosus L.) im semiariden Produktionsgebiet Österreichs. Pflanzenbauwissenschaften. 12(1): 8-21.

Kraig, E. and J.E. Haber. 1980.Messengerribo nucleic acid and protein metabolism during sporulation of Saccharomyces cerevisiae. J. Bacteriol., 144: 1098-1112.

Kulikova, N.A., E.V. Stepanova and O.V. Koroleva. 2002. Mitigating activity of humic substances: Direct influence on biota, in workshop on use of humates to remediate polluted environments: From Theory to Practice Zvenigorod, Russia.

Lazarovits, G. and J. Nowak. 1997. rhizobacteria for improvement of plant growth and establishment. Hort Sci.,32(2): 188-192.

Leaungvutiviroj, C., P. Ruangphisarn, P. Hansanimitkul, H. Shinkawa and K. Sasaki. 2010. Development of a new biofertilizer with a high capacity for N2 fixation, phosphate and potassium solubilization and auxin production. Bioscience, Biotechnology, and Biochemistr., 74(5): 1098-1101.

Leytem, A.B. and R.L. Mikkelsen. 2005. The nature of phosphorus in calcareous soils. Better Crops, 89(2): 1113.

Luo, X.1.,C. Zhong, X. H-xia, P.A. Ying, L. Cheng, S.Z. Fang and C.H. lin. 2008. Effects of bio-organic fertilizer on the growth of cassava and the physical and chemical biological character of soil. Acta Agriculturae BorealiOccidentalis Sinica, 17(1): 167-173. 
Mahmoud, T.R. 2001. Botanical studies on the growth and germination of mahnolia (Magnolia grandiflora L.) plants. M. Sci. Thesis. Fac. of Agric. Moshtohor, Zagazig Univ., Egypt.

Morsi, M.K. ; B. El-Magoli; N.T. Saleh ; E.M. El-Hadidy and H.A. Barakat. 2008. Study of antioxidants and anticancer activity licorice (Glycyrrhiza glabra) extracts. Egyptian J. Nutr. and Feeds, 2(33): 177-203.

Moussa, S.A.M., H.A. AbdEl-Aal and A.M.M. Nofal. 2017. Influence of sources and rates of mineral nitrogenous fertilization and bio-stimulants on garlic productivity and efficiency of its extracts against pathogen activities. Alex. J. Agric. Sci. 62(2): 163-183.

Murphy, J. and J.P. Riley. 1962. A modified single solution for the determination of phosphate in natuural waters. Anal. Chem. Acta., 27: 31- 36.

Nagodawithana, W.T. 1991. Yeast technology. Universal Foods Cooperation Milwauke, Wisconsin. Published by Van Nostrand, New York.

Naguib, M., A.B. El-Sayed and A.K. Khattab. 1987. Effect of cutting the terminal shoots (topping) of cotton plants on the population density of egg-masses of the cotton leafworm (Spodoptera littoralis, Boisd.) and on the cotton yield. Agric. Res. Rev. Vol. (56): 9-15.

Olsantan, F.O. 1986. Effect of apical debudding on growth and yield of okra (Abelmoschus esculentus). Exp. Agric. 22(3): 307-312.

Olasantan, F.O. and A.W. Salau. 2007. Effect of pruning on growth, leaf yield and pod yields of okra (Abelmoschus esculentus (L.) Moench). J. Agric. Sci. 146 (1): 93-102.

Reed, J. 2009. Explaining why pruning encourages plants to thrive. Univ. York. Available on line at: https://www.york.ac.uk/news-andevents/news/2009/pruning-plants/

Rodrigues, M.A., L. Sousa, J.E. Cabanas and M. Arrobas. 2007. Tuber yield and leaf mineral composition of Jerusalem artichoke (Helianthus tuberosus L.) grown under different cropping practices. Spanish J. Agric. Res. 5(4): 545-553.

Rubinstein, B. and M.A. Nagao. 1976. Lateral bud outgrowth and its control by the apex. Bot. Rev. 42(1): 83-113.

Sawicka, B. 2002. Changes in chemical composition of Helianthus tuberosus L. under differentiated nitrogen fertilization. Zeszyty Problemowe Postepow Nauk Rolinczych, No.484: 573-579.

Shafeek, M.R; M.O.Nadia; R.A. Mahmad and M.M.H. Abd El-Baky. 2012. Effect of Bio- organic fertilization on growth and yield of cassava plants in newly cultivated land.Middle East J. Agric. Res., 1(1): 40-46.

Shalaby, T.A. and H. El-Ramady. 2014. Effect of foliar application of bio-stimulants on growth, yield, components, and storability of garlic (Allium sativum L.). Austr. J. Crop. Sci., 8 (2): 271-275.

Snedecor, G. H. and W. C. Cochran. 1980. Statistical methods. $7^{\text {th }}$ ed. Iowa State University Press, Ames., Iowa, U.S.A.
Sorial, M.E.; M.A. Abd El-Fattah and I.M. Ghoneim. 1998. Some attempts to changes the production pattern of globe artichoke to meet export requirements. II. Physiological changes in plant growth, biochemical composition, earliness and productivity of globe artichoke plants (Cynara acolymus, L.) following biofertilizer application and the influence of their interaction on the production pattern of heads. Ann. Agric. Sci., Moshtohor, 36(2): 879899.

Suleiman, N.S. and O. Alhaji. 2015. Effect of Spraying by Organic Fertilizers and Growing Point Pinching On the Growth and Yield of Okra (Abelmoschus esculentus Ls.). Tishreen Univ. J. Res. Sci. 37 (6): 211-220. In arabic.

Taha, S. and K.A. Omar. 2010. Effect of Azotobacter Inoculation, dry dread yeast suspension and varying levels of urea on growth of potato cv. Desiree. Tropentag, September 14-16, Zurich "World Food System- A contribution from Europe.

Tan, K.H. 2003. Humic matter in soil and environment. Principles and controversies, Marcel Dekker,Inc. 270 Madison Avenue, New York.

Tony, H.S.H. 2013. Effect of biofertilization by using three Azotobacter isolates and two levels of mineral nitrogen fertilizer on Jerusalem artichoke (Helianthus Tuberosus L.,) growth, yield and some chemical constituents. J. Amer. Sc. 9 (1): 437-446.

U.S. Salinity Laboratory Staff. 1954. Diagnosis and improvement of saline and alkali soils. U.S. Dep. Agri. Handbook 60.U.S. Gov. Printing Office, Washington, DC.

Wanas, A.L. 2002. Resonance of faba bean (Vicia faba L.) plants to seed soaking application with natural yeast and carrot extracts. Annals. Agric. Sci. Moshtohor, 40 (1): 259-278.

Wanas, A.L. 2006.Trails for improving growth and productivity of tomato plants grown in winter. Annals. Agric. Sci. Moshtohor, 44(3):466-471.

Wein, H.C. and P. L. Minotti. 1988. Increasing yield of tomato with plastic mulch and apex removal. J. Amer. Soc. Hort. Sci., 113(3): 342-347.

Whitney, E.N. and S.R. Rolfes. 1999. Understanding Nutrition. $8^{\text {th }}$ Edition. Belmont, CA: West / Wadsworth.

Winton, A.L. and K.B. Winton. 1958. The analysis of foods. John Wiley and Sons Inc. London 857 p.

Xudan, X. 1986. The effect of foliar application of fulvic acid on water use, nutrient uptake and wheat yield. J. Agric. Res., 37: 343-350.

Zhongyong, C., L. Xinglu, S. Jiang, X. Hexia, C. Minqing, H. Yuanlan, Y.P. Yinghua. 2006. The Effects of Bio-organic Fertilizer on Plants Growth and Root Tubers Yield of Cassava. Chinese Agricultural Sci. Bulletin., 22(11): 202206. 


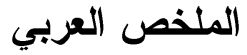

\section{دراسة فسيولوجية على نباتات الطرطوفة المنزرعة فى نوعين من التربة نشوة إبر اهيم أبو الفضل، سامح عبد المنعم محمد موسى، مصطفى أحمد شمة لئل}

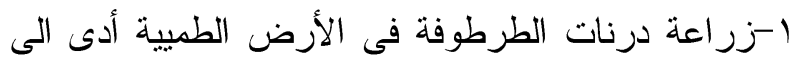
زيادة النمو الخضرى والمحصول الدرنى ومكوناته

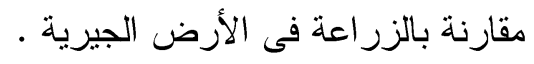

r-كان لعدم تثذيب نهايات الأفرع الخضرية لنباتات

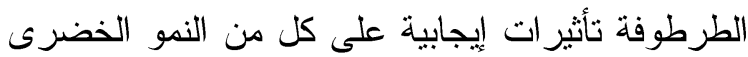

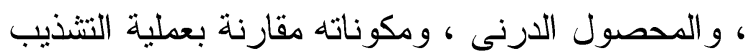

ץ-إضافة Vo كجم نيتروجين / فدان الى جانب الهالكس r + مستخلص الخميرة أدى الى الحصول على نتائج

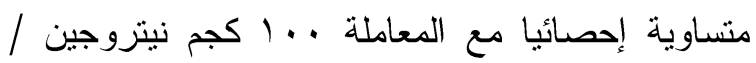

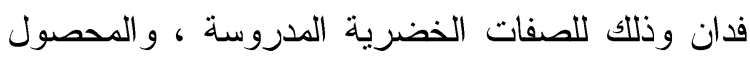

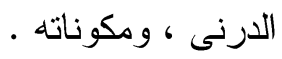

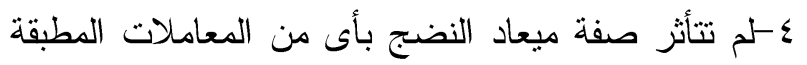

$$
\text { على نباتات الطرطوفة النامية . }
$$

ه-تبين من النتائج أنه يمكن نقليل ربع كمية الأسمدة النيتروجينية المعدنية المضافة الى التربة وتعويض النقص من خلال إضافة خليط من المحفزات الحيوية (هالكس r + مستخلص الخميرة) إلى النباتات النامية

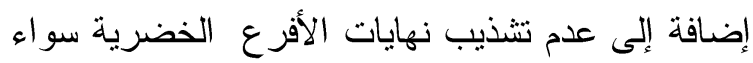
أكانت الزراعة في التربة الطينية أو الجيرية.
أجريت تجربتين حقليتين على محصول الطرطوفة

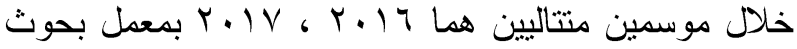
الأراضى الملحية والقلوية ، مركز البحوث الزراعية ،

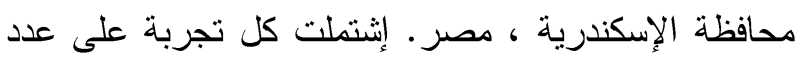

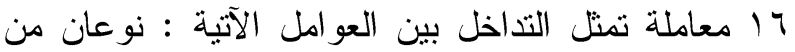
التربة (طينية ،و جيرية) ، معاملتان من النتذيب (إزالة

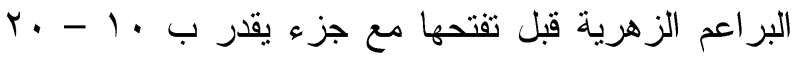

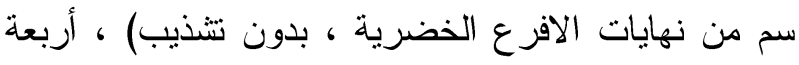

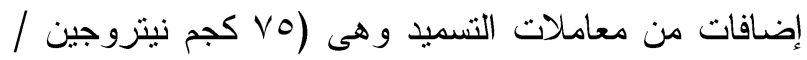
فدان + هالكس r ، Vo كجم نيتروجين / فدان + مستخلص الخميرة ، Vo كجم نيتروجين / فدان + هالكس r +

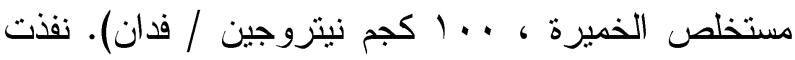
التجربة وتم إجراء التحليل الإحصائى بنظام القطع المنشقة المنشقة بتصميم القطاعات الكاملة العشوائية ذو ثناث مكررات ـ متل نوع التزبة القطع الرئيسية ، بينما منلت معاملات التثذيب القطع المنشقة ، فى حين مثلت معاملات

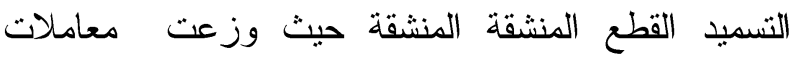
التسميد عليها بطريقة عشو ائية . أهم النتائج المتحصل عليها : 